\title{
A distribution analysis of the central Maya lowlands ecoinformation network: its rises, falls, and changes
}

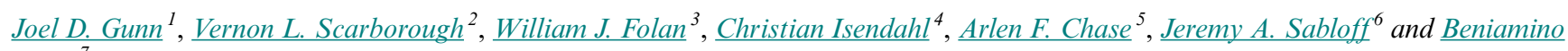
$\underline{\text { Volta }}^{7}$

\begin{abstract}
We report a study of central Maya lowland dynastic information networks, i.e., six cities' external elite ceramic influences, and how they reflect the decision-making practices of Maya elites over 3000 years. Forest cover, i.e., Moraceae family pollen, was added to the network analysis to provide ecological boundary conditions, thus ecologically moderated information networks. Principal components analysis revealed three dominant patterns. First, the networking of interior cities into powerful polities in the Late Preclassic and Classic periods (400 BCE-800 CE). In a second pattern, coastal cities emerged as key entrepôts based on marine navigation (Terminal and Postclassic periods, 800-1500 CE). Climate dynamics and sustainability considerations facilitated the transition. Forest cover, a measure of ecosystem health, shows interior forests diminished as interior cities networked but rebounded as their networks declined. By contrast, coastal forests flourished with networks implying that the marine-based economy was sustainable. Third, in the Classic, the network-dominant coast, west or east, changed with interior polities' political struggles, the critical transition occurring after 695 $\mathrm{CE}$ as Tikal gained dominance over the Calakmul-Caracol alliance. Beginning with the Late Preclassic about 2000 years ago, it is possible to assign names to the decision makers by referencing the growing literature on written Maya records. Although the detectable decision sequence evident in this analysis is very basic, we believe it does open possible avenues to much deeper understanding as the study proceeds into the future. The Integrated History and Future of People on Earth-Maya working group that sponsored the analysis anticipates that it will provide actionable social science intelligence for future decision making at the global scale.
\end{abstract}

Key Words: central Maya lowlands; ceramics; complex-adaptive systems; distribution analysis; forest cover; principal components analysis

\section{INTRODUCTION}

A network analysis of elite pottery types associated with the archaeological records of multiple sites in the central Maya lowlands can be used to illustrate changing degrees of connectedness between these sites over time. We assume that tracking degrees and duration of connectedness are a means to understand the sustainability of systems that operated at these sites. The method that was utilized collected a uniform data set on information exchange among a sample of communities across the region. Principal components analysis (PCA) was then used to determine changing patterns of network cooperation across space and time as mirrored in material culture. This quantitative analysis is further amplified through the use of Maya historical records that provide information relative to decision making over the same temporal span. Based on the patterns observed in these data sets, it is possible to (1) clarify the kind and strength of relations among communities in the central Maya lowlands and communities outside the region; (2) understand how alliances changed over time as adaptive responses to changing technology; (3) provide perspectives on adaptations to climate and the historical ecology of landscape changes; and (4) examine these patterns in relation to independent lines of data on vegetation and resource exchange networks.

Assuming that the delineated patterns are related to a set of conscious decisions on the part of past dynastic leaders at the various sites, we are able to interpret how these decisions fared in terms of the adaptive success (sustainability) of the society and to note whether they offer actionable social science guidance to present-day policy makers. In spite of the worldwide reputation the Maya garnered from the famous 9th century CE "collapse," they are today one of the most successful indigenous societies in the Americas, as measured by a population of 6 million Maya in Mexico, Guatemala, and Belize. What decisions led to this ultimate success? Do they offer us any insights into long-term sustainability of complex adaptive social organizations?

We build on previous background activities by the Integrated History and Future of People on Earth (IHOPE)-Maya working group (see IHOPE History and Problem Orientation) and extends some key ideas developed over the last 6 years into a working model of how the history of Maya civilization originated, developed, and changed over time. It also serves to demonstrate both the importance of temporal resolution for examining change and the usefulness of Maya history as a unitary adaptation to several sets of changed conditions. At a global scale, this exercise contributes to an understanding of how civilizations and nations decide to pursue courses of change over time and are influenced through interactions with their neighbors.

\section{IHOPE HISTORY AND PROBLEM ORIENTATION}

The following study of ancient networks in the central Maya lowlands was carried out under the sponsorship of the IHOPE program. The objective of IHOPE is to provide holistic overviews of cultural regions that will lead to an understanding of human decision making in the context of complex societies of the past and their local, regional, and planetary ecologies (Costanza et al. 2007, Hibbard et al. 2008, Chase and Scarborough 2014b).

\footnotetext{
${ }^{1}$ University of North Carolina Greensboro, ${ }^{2}$ Department of Anthropology, University of Cincinnati, ${ }^{3}$ Centro de Investigaciones Historicas y Sociales, Universidad Autonoma de Campeche, ${ }^{4}$ Department of Historical Studies, University of Gothenburg, ${ }^{5}$ Department of Anthropology, University of Nevada, Las Vegas, ${ }^{6}$ Santa Fe Institute, ${ }^{7}$ Department of Anthropology, University of California, San Diego
} 
Table 1. Integrated History and Future of People on Earth (IHOPE)-Maya area-wide BCE-CE chronology (adapted from Chase et al. 2014).

\begin{tabular}{|c|c|c|c|c|}
\hline Beginning & End & Period Name & Major Events & Symbol \\
\hline CE 1958 & 2000 & Post-IGY & International Geophysical Year Earth System Observations & IGY \\
\hline 1920 & 1958 & Instrumental observation & Carnegie Institution of Washington research & Inst \\
\hline 1550 & 1920 & Historic Maya & Maya integrated into modern nation-states & Hist \\
\hline 1250 & 1550 & Late Postclassic & Northern lowlands heavily occupied & Lpo \\
\hline 1000 & 1250 & Early Postclassic & Florescence of eastern Yucatec coastal sites & Epo \\
\hline 900 & 1000 & Terminal Classic 2 & Florescence of Chichen ltza in northern lowlands & $\mathrm{T} 2$ \\
\hline 800 & 900 & Terminal Classic 1 & Political collapse in the southern lowlands & $\mathrm{T} 1$ \\
\hline 700 & 800 & Late Classic 2 & Regional polities dominate the lowlands & L2 \\
\hline 550 & 700 & Late Classic 1 & Florescence of regional centers in southern lowlands & L1 \\
\hline 450 & 550 & Early Classic 3 & Transition to stratified regional polities & E3 \\
\hline 350 & 450 & Early Classic 2 & Vaulted buildings and Teotihuacan-like elite pottery & E2 \\
\hline 250 & 350 & Early Classic 1 & Widespread appearance of polychrome ceramics & E1 \\
\hline $1 \mathrm{BCE} / \mathrm{CE}$ & 250 & Late Preclassic b & Changes potentially reflective of a minicollapse & $\mathrm{Plb}$ \\
\hline-300 & 1 & Late Preclassic a & Large vertical monumental constructions & Pla \\
\hline-800 & -300 & Middle Preclassic & Large horizontal monumental constructions & $\mathrm{Pm}$ \\
\hline-2000 & -800 & Early Preclassic & First recognizable Maya peoples & $\mathrm{Pe}$ \\
\hline$-3500 \mathrm{BCE}$ & -1500 & Archaic & Paleo-Indian lithic points & $\mathrm{Ar}$ \\
\hline
\end{tabular}

Currently headquartered at Uppsala University and the Swedish University of Agricultural Sciences, Sweden (Tainter and Crumley 2007; http://www.IHOPEnet.org), research groups working independently contribute to an overall view of global historical ecology, both spatially and temporally. In addition to the Maya lowlands study group (known as IHOPE-Maya), other working groups have formed around Imperial Rome, the Southwest United States, China, and the North Atlantic, among others.

The working group for the Maya lowlands was established in 2009 at the School for Advanced Research in Santa Fe, New Mexico, USA. It accepted responsibility for providing perspectives on the Maya lowlands with the goal of developing relevant insights into the evolution of Maya civilization. A specific objective was to explore the role that archaeology and paleoecology can play in contributing to a long-term record of social-ecological interactions for a complex society that spans 3000 years. It is specifically hoped that any insights that are gained from the archaeological record will contribute to our understanding of contemporary environmental and social processes and crises (Chase and Scarborough 2014a).

Parallels between the ancient Maya and our contemporary world of globalization are easily recognized, and several popularized books have been published that deal with issues of collapse, drought, and social management. Diamond (1997, 2004), for example, reviews the effects that the depletion of natural resources and elite management practices had on Maya society in the Terminal Classic period (see Table 1 for time periods) with respect to the Maya collapse. Chapters in Iannone (2014a) consider issues of drought and climate change relative to the ancient Maya, but with clear applicability to modern situations.

Over the last half century, archaeologists have learned to read the ancient hieroglyphic writings of the Maya and have identified several actors who played major roles in their history (Martin and Grube 2008). We combined these humanistic discoveries with quantitative social science studies to produce a broad understanding of decision-making legacies. The complicated interactions between Maya economic and political strategies and lowland environmental dynamics are now thought to be the reason for the well-known 9th century Maya collapse. Rather than a general collapse, the incident is now regarded as a slow "fragmentation" of interior cities during the 8th through 10th centuries CE (Demarest et al. 2004). It is also now evident that there was a reorganization of the Maya economy during and after an extended drought during the 9th century, providing an ideal example of the adaptive behavior of the ancient Maya populations (Sabloff 2007, Turner and Sabloff 2012, Iannone 2014a). Furthermore, it is now evident that the Maya experienced several such reorganizations during their history (Gunn et al. 1995, Brenner et al. 2003, Douglas et al. 2015). Like the Maya, there are parallel sets of reorganizations among other ancient peoples (see, e.g., Hegmon et al. 2008, Cline 2014, Bocinsky et al. 2016, for the American Southwest and eastern Mediterranean Bronze/Iron Ages). It is the ultimate objective of IHOPE-Maya to sort out the various developmental trajectories represented in the archaeological records of the ancient Maya to suggest constructive management and decision-making practices for the contemporary world.

In addition to collecting Maya archaeological data in accord with a unified set of rules we have reported in the Data configuration and collection section, the baseline coverage of IHOPE-Maya study zones (Fig. 1) was organized and published in 2014 (Chase and Scarborough 2014b). A computer simulation of ecological and cultural interactions in the Maya lowlands after about 1000 BCE was also developed to provide temporal and processual depth to the studies (Heckbert et al. 2016; see http://IHOPEnet. org/MayaSim/); this simulation was able to show that constraints on resources limited the expansion of Maya subsistence. Additionally, the internal workings of Maya elite society were documented and showed that their ancient displays of power were focused on symbols of social status. On a personal level, these symbols included material items made from jadeite, hematite, and seashells; on a societal level, these symbols were made explicit in their carved monuments and their pyramids and palaces set in reconfigured landscapes (Schele and Freidel 1990, Reents-Budet 
1994, Prufer et al. 2011). When placed within a temporal framework, changes to these symbols and to Maya centers may be encompassed in a concern for path dependent decision making (Chase and Chase 2014).

Fig. 1. Map of the Yucatan Peninsula showing Integrated History and Future of People on Earth (IHOPE)-Maya zones of interest (adapted from Chase et al., 2014).

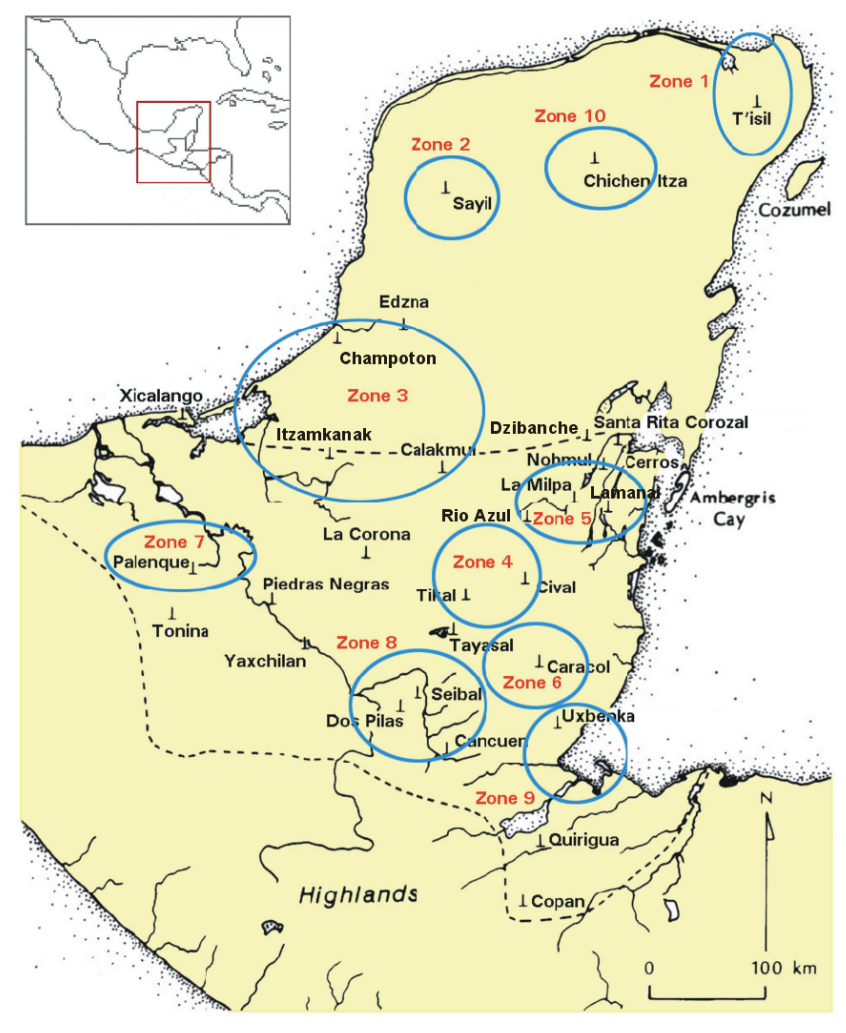

The IHOPE-Maya research design closely parallels the "integrated research tools" design proposed by Miller and Morisette (2014) for making "actionable social science intelligence" of global change information for future decisionmaking proposes through the use of distribution analyses, simulations, and well-defined scenarios. Heckbert et al.'s (2016) work noted previously represents a simulation approach to ancient Maya development. The work we report is a distribution analysis of ancient Maya elite ceramics and forms the initial block in a scenario-building effort.

\section{DYNASTIES AND DYNAMICS: ASSUMPTIONS OF THE STUDY}

We assume that tracking degrees and duration of connectedness are a means to understand the sustainability of systems. This is based on the idea that multigenerational governance such as Fukuyama $(2011,2015)$ attempts to define for modern states is based in mutually beneficial relationships between the governing and the governed. In the Maya lowlands, such relationships have been recognized as dynasties. To quote Martin and Grube (2008:14), "The interests of the humble farmer and the high king were entwined." At the level of national politics, charismatic leadership, which is to say agents of states, strove to extend the reach of their political units adding a dynamic character to the size and duration of states. This structure is clearly evident in the low-density, low-coercion, tropical urbanism of the lowlands as modeled by Scarborough and Valdez $(2009,2014)$ and McAnany et al. (2015). They propose that were an autocrat too overbearing, the population could simply vote with its feet and fade away into the jungle so to speak. Playing an important role in this pageantry were "painted vessels show[ing] evocative scenes of courtly life, with enthroned lords surrounded by wives and retainers, often receiving the homage of vassals delivering mounds of tribute" (Martin and Grube 2008:15-16). Many of these vessels containing both renderings of royal life among the Maya and associated texts have been extensively published (Fig. 2; e.g., Kerr 1989-1996, Reents-Budet et al. 2011).

Fig. 2. Painting from a vessel showing a king (seated on platform) in conversation with two of his lords who are delivering tribute. The symbols along the top and between the figures are written descriptions of the proceedings (reproduced with permission from Reents-Budet 1994:174).

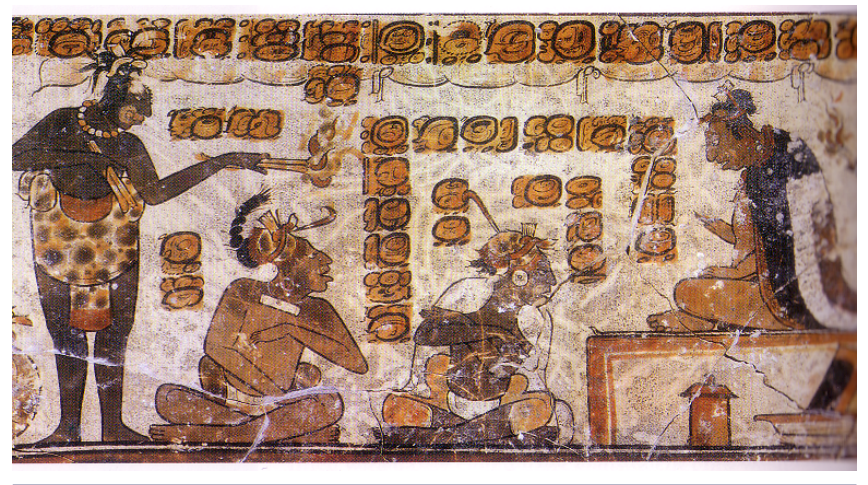

Elite networks are reflected in elaborate ceramics as has been demonstrated in surprising detail by Reents-Budet et al. (2011). Maya lowlands elite ceramics can be identified with their manufacturers, users, and networks as can be seen in the case of two of Calakmul's kings during the Calakmul golden age, about 550 to $700 \mathrm{CE}$ (see Table 1). Of special importance are two elite ceramics pieces (Reents-Budet et al. 2011; Fig. 3).

Fig. 3. Hieroglyphic texts indicate that the vase (left) belonged to Yuknoom Ch'een II (the Great) and a plate (right) to Yuknoom Yich'aak K'ahk', Ch'een II's heir (names in squares). Reproduced with permission.

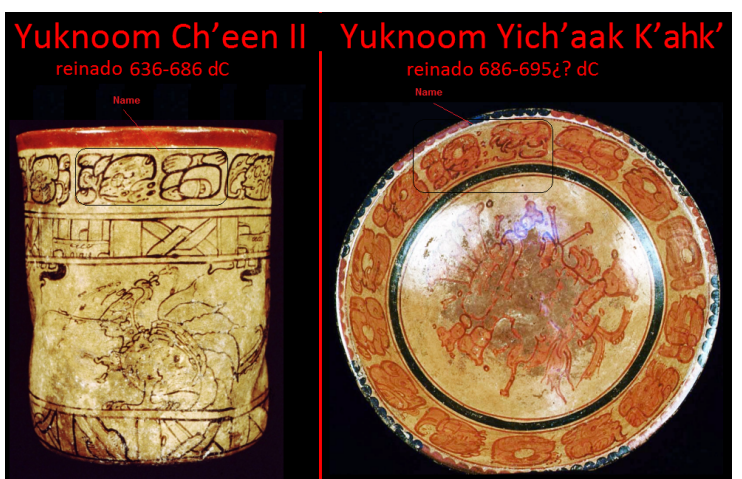


The pieces were recovered by Carrasco Vargas et al. (1999) from Tomb IV, Structure II and analyzed by Sylviane Boucher and Yoly Palomo. One is a plate (Palmar Orange polychrome) containing the name of Yuknoom Yich'aak K'ahk' (ruled 686-695? CE). Another is a vase (codex style) with the name of his father Yoknoom Ch'een II (ruled 636-686 CE), otherwise known as "the Great." Both ceramics have unusual yellow backgrounds that would normally mark them as coming from the southern region of the Mirador basin, probably El Tintal (Fig. 4, inset map). However, neutron activation of pastes indicates that the pieces were actually manufactured in Calakmul (Reents-Budet et al. 2011:849). Other pieces show that before its golden age, Calakmul's elite residents obtained their highly prized codex-style pottery from Nakbe, but during the reign of either Yuknoom Yich'aak K'ahk' or his father, they decided to set up a workshop in Calakmul itself.

Fig. 4. Mapping the sources of elite ceramics into Calakmul. The city names along the top are from sources outside the Mirador area. Upward-facing arrows inside the circle, the Mirador area, point to the structures in Calakmul from which ceramics from Tintal and Nakbe were recovered. Downwardfacing arrows from Nakbe point to rare cases in which elite ceramics were sent outside the Mirador area.

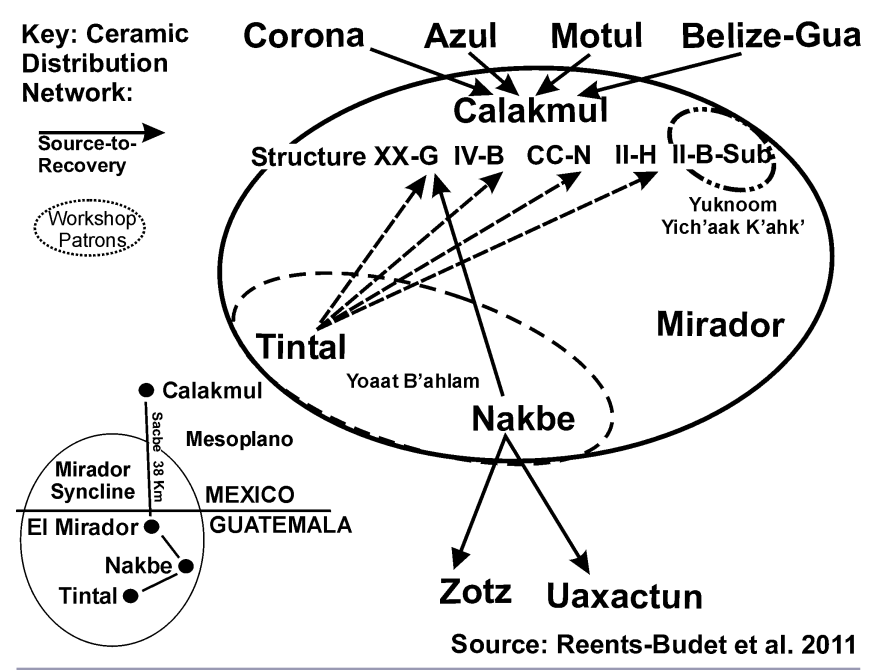

From Reents-Budet et al.'s (2011) research, it has become clear that exchange of codex pottery was part of a feasting and obligation network that reflected the relationships of ruling dynasties during the period of their manufacture and use (550-850 $\mathrm{CE}$ ). Neutron activation of thousands of ceramic pieces from across the lowlands allows a preliminary reconstruction of the exchange networks with which the Calakmul dynasty was involved (see Fig. 4: arrows indicate the source and destination of the pottery; in the case of Calakmul, specific structures and buildings are designated). There are, of course, many other networks to be identified. As will become apparent in subsequent discussions, however, this network demonstrates how individuation of pottery can act as an aid in the interpretation of the decisions made by dynastic figures during their tenure and discovered by dynastic-level analysis such as we do subsequently.

Thanks to these graphic insights along with the ability to better understand Maya writing (e.g., Coe and van Stone 2005, Martin and Grube 2008), we can now combine these very humanistic visions of leadership with traditional archaeological approaches to the analysis of material culture to understand how networks were modified over time to facilitate adaptation to changing contexts. Looking at the histories of the shared elite traits that include polychrome portrait ceramics, public architecture embellished with stucco decoration, and carved stone monuments celebrating alliances and victories helps us better understand how decisions about technology permitted the ancient Maya to build sustainable cities capable of water management through the dry season (e.g., Chase 2016), thus aiding the long-term sustainability of dynasties.

These longitudinal histories also help us understand the adaptations to climate and landscape changes made by the Maya. It has become clear through the study of pollen and sediment cores from rivers and lake bottoms that the Maya lowlands have been subject to radical environmental changes, both in the past and today. These may come from global influences on regional climates (Gunn et al. 1995, Gunn and Folan 2000, Brenner et al. 2003), anthropogenic modification of local landscapes (Chase and Chase 2014, Lentz et al. 2014), or more usually both (Chase and Weishampel 2016). Depending on the utility of vegetation species that provided construction, shade, and food, these species can be used as indications of anthropogenic modification of a local landscape (Hightower et al. 2014).

The lengthy archaeological record also permits us to clarify the relations between communities in the central Maya lowlands and communities outside the region. The Maya lowlands are rich in resources required throughout the peninsula and the Mesoamerican area, and its archaeological record can be used to demonstrate a panoply of changing alliances with external powers over time. This is particularly the case with communities such as those of the lower Motagua River valley in Guatemala, which controlled the flow of important sources like obsidian and jadeite that were external to the peninsula. Maya elites fared variably in the adaptive success of their decisions. When these decisions are studied relative to other variables in the system, they have the ability to offer actionable social science guidance that may be of use to modern policy makers as suggested by Miller and Morisette (2014).

\section{DATA CONFIGURATION AND COLLECTION}

With the organization of the IHOPE-Maya working group, a Yucatan Peninsula-wide study was envisioned. An initial study was done on data that were readily collectable from 10 representative zones in the Maya area for which both archaeological and environmental data could be correlated (see Fig. 1). Even though the selection was based on available longterm studies and key personnel, it proved to be a reasonable approximation of a uniform distribution sample of the lowlands area. Jeremy Sabloff and Arlen Chase were asked to develop a chronology that could be applied area-wide while accommodating local variations (see Table 1). Because of the long-standing importance of ceramics in Maya studies, this material class was used to code each zone for outside influences on elite and nonelite ceramics for a key city in each zone over all time periods. Outside influences could be through commercial exchanges or through stylistic incorporation of external designs (modes) in local pottery. These zones were coded by individuals familiar with the ceramics in each zone. Initially, five zones, i.e., Zone 2 Sayil- 
Table 2. Integrated History and Future of People on Earth (IHOPE)-Maya distribution analysis data. IHOPE-Maya subperiods (see Table 1), dates BP, elite ceramic interactions, and forest cover.

\begin{tabular}{|c|c|c|c|c|c|c|c|c|c|c|}
\hline \multirow{2}{*}{$\begin{array}{l}\text { Name } \\
\text { Phase }\end{array}$} & \multirow{2}{*}{$\begin{array}{c}\text { Time } \\
\text { Date BP }\end{array}$} & \multicolumn{6}{|c|}{ Ceramics } & \multicolumn{3}{|c|}{ Forests $^{\dagger}$} \\
\hline & & Champoton & Lamanai & Calakmul & Rio Azul & Caracol & Palenque & Silvituc & Peten Itza & Juan Piojo \\
\hline Hist & -400 & 3 & 0 & 0 & 0 & 0 & 0 & 1 & 3 & 2 \\
\hline Lpo & -700 & 3 & 3 & 0 & 0 & 0 & 0 & 1 & 2 & 2 \\
\hline Epo & -950 & 2 & 3 & 1 & 0 & 0 & 0 & 3 & 2 & 2 \\
\hline $\mathrm{T} 2$ & -1050 & 2 & 2 & 2 & 2 & 0 & 0 & 1 & 1 & 1 \\
\hline $\mathrm{T} 1$ & -1150 & 3 & 3 & 2 & 3 & 3 & 2 & 2 & 1 & 1 \\
\hline L2 & -1250 & 2 & 3 & 3 & 3 & 3 & 1 & 1 & 1 & 1 \\
\hline L1 & -1400 & 2 & 2 & 3 & 2 & 3 & 1 & 3 & 1 & 1 \\
\hline E3 & -1500 & 2 & 2 & 3 & 2 & 2 & 3 & 2 & 1 & 2 \\
\hline E2 & -1600 & 1 & 3 & 3 & 2 & 3 & 2 & 2 & 1 & 2 \\
\hline E1 & -1700 & 1 & 2 & 2 & 2 & 2 & 2 & 1 & 1 & 2 \\
\hline $\mathrm{Plb}$ & -1949 & 2 & 2 & 3 & 2 & 3 & 2 & 3 & 1 & 1 \\
\hline Pla & -2250 & 3 & 0 & 3 & 0 & 3 & 2 & 1 & 1 & 1 \\
\hline $\mathrm{Pm}$ & -2750 & 2 & 0 & 1 & 0 & 2 & 0 & 2 & 2 & 1 \\
\hline $\mathrm{Pe}$ & -3950 & 1 & 0 & 1 & 0 & 0 & 0 & 3 & 2 & 1 \\
\hline $\mathrm{Ar}$ & -5450 & 1 & 0 & 0 & 0 & 0 & 0 & 3 & 3 & 1 \\
\hline
\end{tabular}

${ }^{\dagger}$ Converted to three state variables.

Sabloff, Zone 3 Calakmul-Domínguez Carasco, Zone 4 Rio AzulValdez, Zone 5 Lamanai-Valdez, and Zone 6 Caracol-A. and D. Chase, were coded for external ceramic influences on both elite and nonelite ceramics (Gunn and IHOPE-Maya members, unpublished manuscript). Eventually, two other zones and a coastal city in Zone 3 were added to the sample, i.e., Zone 1 Ti'silFedick, Zone 3 Champoton-Forsyth, and Zone 7 PalenqueLiendo, to expand coast-to-coast coverage. We used six cities/ zones (Fig. 5), focusing only on the elite segment of the ceramic data.

Fig. 5. Central Maya lowlands, geology and topography. Cities used in this study and Karstic Mesoplano/Coastal Plain topography (B. Volta).

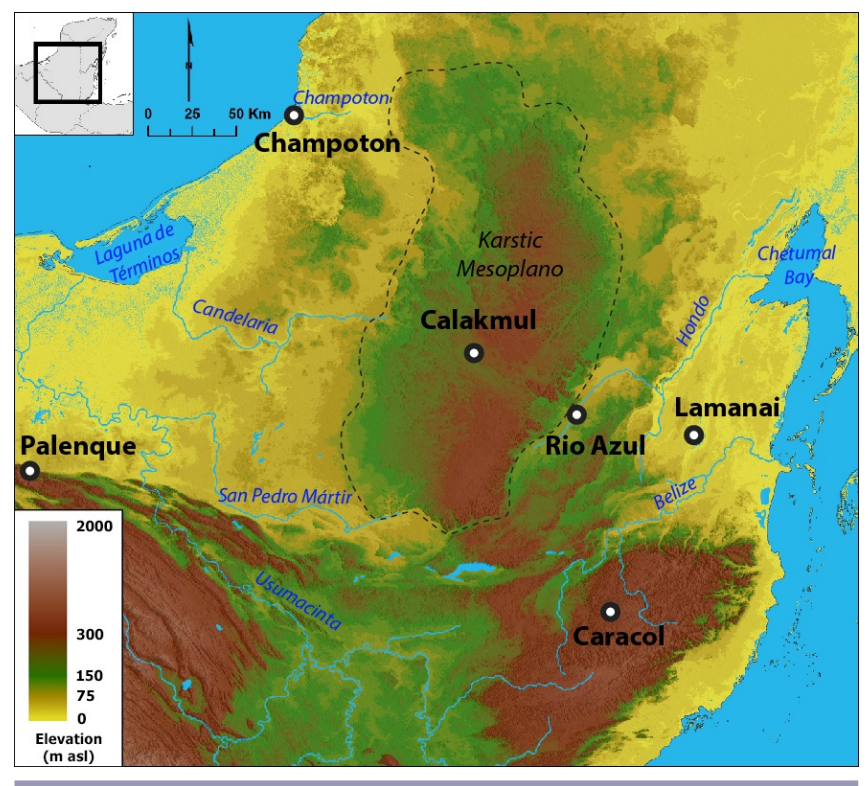

\section{Elite ceramics interaction coding}

We used elite ceramic codes from six of the central lowland cities. Codes were as follows: 1 , no external influence; 2 , some external influence; and 3, a great deal of external influence. To provide a standard context for this activity, each expert was supplied with a spreadsheet containing the Table 1 chronology, the meaning of the codes, and instructions on how to approach the coding. The elite ceramics codes obtained for each zone/city are in Table 2.

Relevant background information on the zones coded can be found in Chase and Scarborough (2014b). The zones coded and the experts who coded them are as follows:

- Zone 3, Coastal aspect, the west coast aspect (see Fig. 1): Don Forsyth was asked to code the ceramic interactions for Champoton, an important west coast maritime trading center recently investigated by Folan et al. (2007). Coding Champoton provides maritime-terrestrial detail within Zone 3 and a maritime balanced perspective on the eastwest axis to maritime Laminai (see Zone 5), connected by river to the eastern Belize coast. Champoton is located at the mouth of the Champoton River, which provides access to the Edzna Valley and its considerable agricultural potential. Further inland, the Desempeño River continues the Champoton system making links through Oxpemul to the Escondido River on the east side of the peninsula (Volta and Gunn 2012).

- Zone 3, Mesoplano (Folan et al. 2011) aspect: Rosario Domínguez Carrasco coded the ceramic interactions for Calakmul. Calakmul is located on a promontory overlooking the El Laberinto passage across the peninsula in the more western and northern areas of the central lowlands in the state of Campeche, Mexico. It was a center of population and power especially during the early phases of the Late Classic. In alliance with Caracol, Calakmul subdued Tikal in the early 6th century and remained in power until $695 \mathrm{CE}$, at which time Tikal reversed the dominance (Martin and Grube 2008:37). Its relatively dry 
$(1000-2000 \mathrm{~mm} / \mathrm{yr})$, elevated location required that it be engineered as a city to collect and store water to sustain populations through the dry season. It was about $40 \mathrm{~km}$ from permanent water in northwestern Guatemala.

- Zone 4, Mesoplano aspect of Holmul basin: Fred Valdez coded the ceramic interactions for Rio Azul to represent this zone. It is located in northeastern Guatemala. As such, it represents Uaxactun, Tikal, El Zotz, and other communities around the Holmul passage across the peninsula. Along with Tikal, it was influenced by Teotihuacan beginning in the 4 th century CE and rose to be a first-class power in the 8th century CE. Like Calakmul, the cityscape was located in the edge of the elevated Mesoplano and carefully engineered to collect and store water through the dry season. It too was $40 \mathrm{~km}$ from the nearest permanent water.

- Zone 5, the east coast in Belize: Fred Valdez recorded codes for ceramic interaction for Lamanai located on the New River in Belize. Lamanai has a long history of occupation (Hanna et al. 2016) being particularly important in the Postclassic subperiods. It was connected to the Caribbean Sea near Altun Ha by an east-west route (Pyburn 2008).

- Zone 6, the Vaca Plateau at Caracol: Arlen Chase and Diane Chase coded the ceramics for Caracol on the west side of the Maya Mountains in western Belize. Caracol harbored a large population in a highly engineered terrain recently revealed in great detail by light detection and ranging mapping (Chase et al. 2011). Caracol was instrumental in subduing Tikal in the 6th century CE. It continued to be occupied through the 9 th century droughts as other parts of the peninsula were abandoned, probably because its mountainous location and expansive water control infrastructure afforded it precipitation and water storage in the worst of climatic times for the rest of the peninsula.

- Zone 7, the southwest central lowlands at Palenque: Coded by Rodrigo Liendo. This city is located in the piedmont of the Sierra de Chiapas near the Usumacinta River. Also against the mountains, it is located in a high rainfall area (2000-3000 mm/yr). It was apparently a strategic location of substantial importance because the Calakmul state made repeated military visits to the city constituting the longest range conquest efforts of any lowland polity (Martin and Grube 2008). In the perspective of cross-peninsular trade networks, Palenque appears to control one of the outlets to the western sea and thus to the western peninsula, the Gulf coast, and the Mexican highlands. Its complex art and architecture reflect the wealth accumulated from this role in the economic system. Even so, the dynastic range of the city is relatively short, lasting from about 430 to $800 \mathrm{CE}$ (Martin and Grube 2008) and reflecting a relatively brief engagement with the international economic system.

\section{Forest cover coding}

The ceramic interactions for the six central lowland locations were coupled with three sets of observations on forest cover to provide measures of forest extent and human impacts on ecosystems through the phases of lowland Maya history. Taken together, the combination of ceramics interactions and forest cover represent the central lowland ecoinformation system. The samples selected provide windows on the elevated interior and the coasts.

- Zone 3 interior: The pollen core from Laguna Silvituc in Campeche by Torrescano-Valle and Islebe (2015) reformatted by Gunn for this analysis. Moraceae, i.e., tropical forest hardwoods and fruits, and ficus (Ficus sp.), i.e., lesser woods used mostly for shade and very poor fire wood, are summed for this component. This pollen represents the drier ( 1000-2000 mm/yr precipitation; Sharer and Traxler 2006) northwest of the study area.

- Zone 4 interior: Lake Petén Itza from the eastern interior of the central lowlands (Brenner et al. 2003) reformatted by David Lentz for this analysis. It represents the elevated southeast interior of the peninsula, a modestly moist ( $2000-3000 \mathrm{~mm} / \mathrm{yr}$ precipitation) aspect of the peninsula.

- Zone 5 maritime: Laguna Juan Piojo near Dos Hombres from coastal Belize (Scarborough et al. 2003) reformatted by David Lentz for this analysis. It represents the southeast coast of the peninsula, a moist aspect of the landform. Another coastal core is now available for the southwest coast from the Laguna de Terminos (Torrescano-Valle et al. 2012). However, although the sediments appear to be resolved in time equivalent to the IHOPE-Maya timescale, the radiocarbon chronology for the Panlao core is not yet equivalently refined. Preliminary work with the Panlao data for this analysis appears to be promising. We used Laguna Juan Piojo to represent both coasts. This is justified by the fact that both coastal areas appear to have similar supportive relationships to their forests that have lasted into the modern era for ethnographic observation (Gunn et al. 2002, Ford and Nigh 2009).

Forest cover is taken to represent the inverse of demand on ecosystem services by human communities for energy, commodities, and infrastructure. Also included as a variable were the beginning dates of the IHOPE-Maya chronology observed in all IHOPE-Maya coding. A brief label (see Table 1) for each period was also included for labeling of plots. The data matrix (see Table 2) was 11 variables by 15 subperiods: 1 subperiod label, 1 beginning date, 6 elite ceramic interactions, and 3 forest cover codes.

\section{STUDYING COMPLEX ADAPTIVE SYSTEMS WITH PRINCIPAL COMPONENTS ANALYSIS: A MAYA LOWLANDS EXAMPLE}

We view Maya decision making through analysis of material culture. In the PCA and complex adaptive systems section, we offer a brief example from the Classic period on how written records can contribute to a more humanistic point of view on a similar sequence of events.

The previously outlined data were analyzed using PCA. PCA is an inherently multivariable method that sorts important patterns in interactions between subsystem components into principal components. It is therefore an obvious potential tool for use in the study of complex adaptive systems. Component scores calculated from the principal components delineate a way of visualizing changes in interactions through time. We therefore apply it to understanding the degree and timing of social networking among urban elites. 
Fig. 6. Key components of the Maya lowlands complex adaptive system.

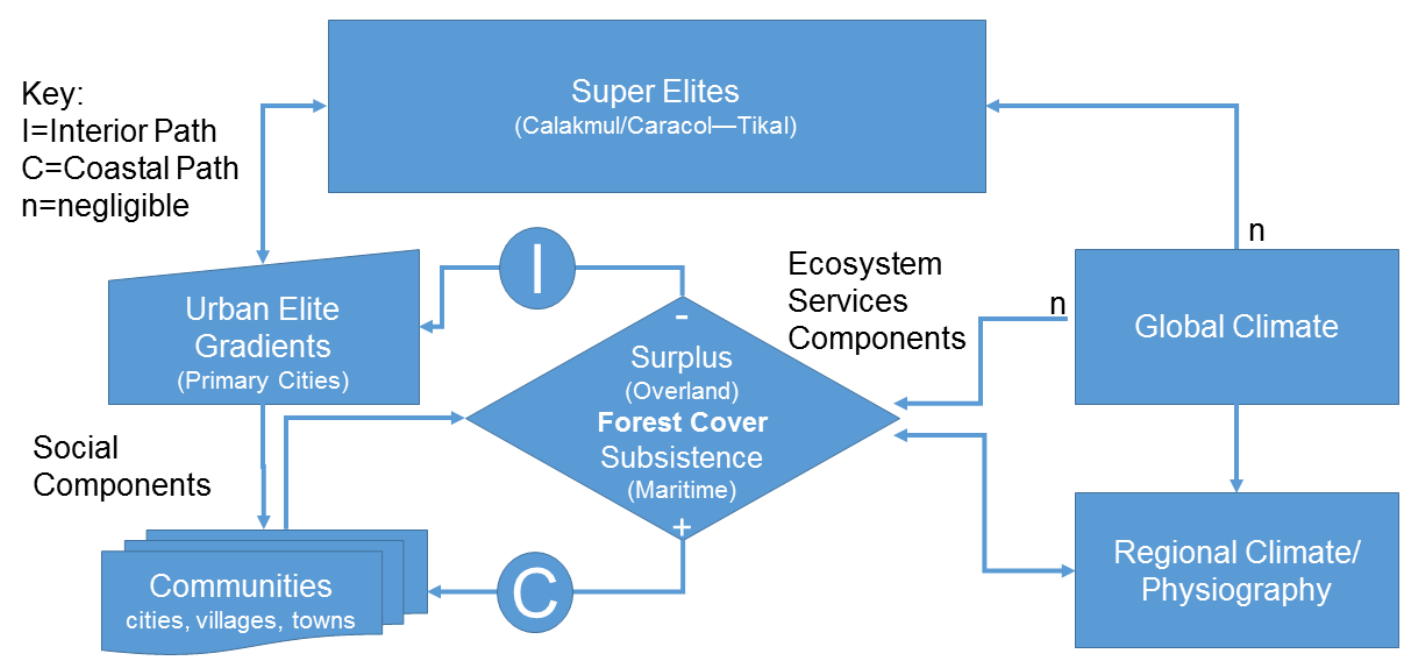

The Maya lowlands as a complex adaptive system

A system is a group of interacting components (for a similar definition, see Bogucki 2003, Pyburn 2008). The special configuration of Maya lowland social components has been previously studied, as have the social components for the ancient Greeks in the Old World and the Mogollon in the American Southwest. Each component is self-contained politically but interactive commercially with other components. This social structure was defined by Hansen (2000) as a "city-state culture" (for discussion of this model, see Pyburn 2008). The city-state culture model is thought to be testable in the usual scientific sense. This provides an especially important link to normal science in a combined science/humanist perspective such as that we offer in this analysis.

We have used elite ceramics from archaeological sites to represent the social components (Fig. 6). Forest cover drawn from lake bottom pollen cores represents the local and global ecosystem input. Forests are impacted by human management, physiography, and local and global climate conditions. The urban elites who commanded parts of the economy in the Maya cultural system (Masson and Freidel 2012) exchanged elaborate ceramics as gifts in lieu of direct control of commodities. They draw on ecosystem services to fuel urban hierarchies that exert control over expanding systems of communities. The difference between a positive and negative ecosystem balance is the cost of transportation. Overland transport costs about 20 times more than maritime transport.

In the central lowlands El Mirador area, many elite ceramics originated at Nakbe south of Calakmul (Reents-Budet et al. 2011). Also, copying ceramic designs from other communities has been demonstrated through neutron activation of locally produced ceramics (Domínguez Carrasco 2008, Reents-Budet et al. 2011). Nevertheless, copying qualifies as information exchange and therefore indicates outside influence in the ceramic code.

Some time ago, students of systems viewed stable systems as ideal. Stable systems imply negative feedback to maintain their steady states. If all of the components of a system feed into each other to a similar degree all of the time, the system would be stable and unchanging, and, as systems theorists say, it would be "in equilibrium." However, such stable systems seldom if ever exist in the biological and social worlds, because, when they are nudged by outside components, they tend to loose track of their feeds to other components and collapse (Kauffman 1995, Capra 2002, Bentley 2003, Cline 2014). They are nonadaptive. The alternative hypothesis is that positive feedback systems are, curiously, more stable (Bentley 2003). Because the components are always nudging each other, they are always ready for another outside nudge. To be resilient in the short term, they must inherently hover close to instability and collapse. As in most societies, the longterm history of the Maya in the lowlands shows evidence of both systems adapting and systems becoming unstable and collapsing. The ones that adapt are therefore "complex adaptive systems."

The cost of short-term stability through positive feedback, however, has unfortunate long-term implications. In positive feedback systems, the components are in competition with each other, so there is advantage obtained by increasing the intensity of relationships. "Peer polities" (for a list of similar constructs and causes, see Cline 2014) and various other structures in the anthropological literature are examples of complex adaptive systems. The disadvantage of positive feedback systems is that they are inherently growth systems, so they ultimately overshoot their resources, requiring reorganizations or resulting in collapses.

In the central Maya lowlands complex adaptive system, components can be represented as cities governed by elites. Elites represent successive generations of rulers (agents) who aggrandize sufficient surpluses (Pyburn 2008) to sustain themselves across generations. As van der Leeuw (2007) points out, elites give motivation and direction to their communities. The tendency among Maya city elites was to extend their power over time by means of military threats to other cities (Martin and Grube 2008), giving a positive feedback dynamic to the bureaucratic systems. The rise of an elite in one city at the expense of others leads to a 
Table 3. Correlation/significance matrix.

\begin{tabular}{|c|c|c|c|c|c|c|c|c|c|c|}
\hline & Date & Champoton & Lamanai & Calakmul & Rio Azul & Caracol & Palenque & Silvituc & Peten Itza & Juan Piojo \\
\hline Date & 1.00 & 0.01 & 0.01 & 0.20 & 0.09 & 0.28 & 0.26 & 0.03 & 0.09 & 0.04 \\
\hline Champoton & 0.59 & 1.00 & 0.40 & 0.39 & 0.39 & 0.41 & 0.50 & 0.06 & 0.50 & 0.50 \\
\hline Lamanai & 0.61 & 0.07 & 1.00 & 0.09 & 0.00 & 0.16 & 0.13 & 0.38 & 0.02 & 0.12 \\
\hline Calakmul & 0.23 & -0.08 & 0.37 & 1.00 & 0.00 & 0.00 & 0.00 & 0.48 & 0.00 & 0.23 \\
\hline Rio Azul & 0.36 & -0.08 & 0.64 & 0.72 & 1.00 & 0.01 & 0.01 & 0.33 & 0.00 & 0.31 \\
\hline Caracol & 0.37 & -0.07 & 0.74 & 0.67 & 0.82 & 1.00 & 0.00 & 0.47 & 0.00 & 0.17 \\
\hline Palenque & 0.18 & 0.00 & 0.31 & 0.77 & 0.61 & 0.64 & 1.00 & 0.39 & 0.00 & 0.32 \\
\hline Silvituc & -0.50 & -0.43 & -0.08 & -0.01 & -0.12 & 0.14 & -0.08 & 1.00 & 0.28 & 0.18 \\
\hline Peten Itza & -0.30 & 0.05 & -0.44 & -0.96 & -0.75 & -0.66 & -0.81 & 0.15 & 1.00 & 0.29 \\
\hline Juan Piojo & 0.51 & 0.03 & 0.39 & -0.20 & 0.04 & 0.13 & 0.14 & -0.34 & 0.11 & 1.00 \\
\hline
\end{tabular}

Above diagonal 1.00s are one-tailed significance tests $(\mathrm{p}=<0.05)$, below are correlation coefficients.

broader aggregation of cities. These aggregations rise and fall with the fortunes of the elites. In the end, they serve as the state-level (supercity) actors in the lowland milieu.

Fukuyama (2015) uses decision paths to work out how societies move from their original, patrimonial social organization to mutually beneficial bureaucracies, in this case some form of dynasty (e.g., Martin and Grube 2008). The appeal of the decision path methodology is that it not only is sufficiently known in the modern era to make sense out of the cultural evolution of modern states, as Fukuyama (2015) does, but also has the potential to extend and bridge this thought process into the past, as has been done for the ancient city of Caracol (Chase and Chase 2014) and as we attempt to further.

The framework for decision paths is culture. Fukuyama describes the bottom-up evolution of societies as being guided by laws developed from generations of common practice, such as occurs in English common law. We can add that most cultures probably do this orally rather than in writing. In Fukuyama's (2015) work, we have an example of application to a full suite of modern states, the social organizations we see as the institutional stakeholders in the modern decision-making process concerning the planetary future. For purposes of integrating with the complex systems thought process, we will consider culture to be an emergent property of daily interactions in a population. There has been a long-standing discussion of culture in this sense dating back to the "invisible hand" proposals of Adam Smith (1759, 1776) beginning in the late 1700s and later including Durkheim (1893/1960, 1897/1951) and Kroeber (1917), among others. Redfield and Villa Rojas (1934) discussed it locally in the context of their Chan Kom studies, and the concept is naturally used in the recent complex systems modeling literature (e.g., Holland 1998, Mitchell 2011, Miller and Morisette 2014). In the cases of ancient Maya states, culture is particularly important because it, rather than an institutional state, was the framework in which decisions were made.

We found elites in the archaeological and historical record to be sharers and consumers of ceramic vessels of preferred elaborate designs. The more exchanges of vessels of these designs there are in cities, the more interaction is inferred from the archaeological record in our data. Growing interaction measured by elaborate ceramics implies growth in the social network. We are also interested in the relationship between these elites and their cities in relation to their resource environment as represented by forest cover. Are they using it up or replenishing it? This in large part determines whether a trajectory is taken toward collapse or sustainability.

\section{PCA and complex adaptive systems}

Analyzing systems with a few components is somewhat in the range of comprehension of most people including students of such systems, among them archaeologists and historians. Most popular in the history of studies of civilizations has been twocomponent systems composed of one society and one external variable. Gordon Childe (1936), for example, suggested that the cause of human societies becoming civilized was drying of environments that lead people to aggregate in close quarters around oases (for the opposite hypothesis, see Day et al. 2007).

Going beyond a couple of variables requires methods of analysis that help the researcher to see appropriate relationships between the components in greater numbers and how they change together or separately over time. Environmental and cultural systems commonly involve tens or hundreds of components, so they are far beyond the reach of anyone unaided by an analytical technology. In the system we studied, there are 10 components: 6 elites, 3 forests, and time. This cultural space-time distribution requires analytical methods beyond a simple two-variable, causeand-effect analysis. One such methodology is PCA (see PCA in Rummel 1970). Basic training in PCA is available online (see ftp:// statgen.ncsu.edu/pub/thorne/molevoclass/AtchleyOct19.pdf).

PCA answers the following questions about what has happened or is happening in a complex adaptive system:

1. What are the relationships between pairs of components of a system, and are any statistically significant? (For correlation, see Table 3.) For PCA to be effective, it requires that some, but not all, of the components have strong correlations.

2. To what degree does a component interact (correlate) with all the other components? If there is no interaction, a system does not exist. (For communality, see Table 4.)

3. What components of a system group together into subsystems? In this case, are there communities that are acting in concert? (For principal components, see Table 4.)

4. What components participate in (nudge) more than one subsystem? This shows which components are being 
Table 4. Principal components analysis.

\begin{tabular}{|c|c|c|c|c|c|c|c|c|}
\hline \multirow[t]{3}{*}{ Patterns } & 1 & 2 & 3 & 4 & 5 & Communalities & & \\
\hline & \multicolumn{5}{|c|}{ Principal Components } & & \multirow{2}{*}{\multicolumn{2}{|c|}{ Locations/Artifacts }} \\
\hline & Interior & Coastal & Coasts & Lamanai & Palenque & & & \\
\hline \multicolumn{9}{|l|}{ Components } \\
\hline Date & 0.48 & 0.81 & 0.00 & 0.16 & 0.10 & 0.93 & & Time \\
\hline Champoton & 0.10 & 0.63 & -0.65 & 0.14 & 0.37 & 0.98 & Coastal & \\
\hline Lamanai & 0.63 & 0.37 & 0.47 & 0.43 & 0.02 & 0.94 & Cities & \\
\hline Calakmul & 0.90 & -0.29 & -0.07 & -0.09 & 0.02 & 0.92 & & Elite \\
\hline Rio Azul & 0.86 & -0.08 & 0.12 & 0.25 & -0.23 & 0.88 & Interior & Ceramics \\
\hline Caracol & 0.83 & -0.29 & -0.24 & -0.13 & 0.17 & 0.93 & Cities & \\
\hline Palenque & 0.81 & -0.15 & 0.05 & -0.45 & 0.21 & 0.94 & & \\
\hline Silvituc & -0.20 & -0.66 & 0.36 & 0.30 & 0.55 & 0.99 & Interior & \\
\hline Peten Itza & -0.93 & 0.11 & 0.04 & -0.04 & 0.12 & 0.90 & & Forests \\
\hline Juan Piojo & -0.02 & 0.65 & 0.61 & -0.43 & 0.14 & 1.00 & Coastal & \\
\hline Eigenvalues & 4.47 & 2.25 & 1.22 & 0.80 & 0.60 & & & \\
\hline Variance $\%$ & 45 & 23 & 12 & 8 & 6 & & & \\
\hline Cum. var. $\%^{\dagger}$ & 45 & 67 & 79 & 87 & 93 & & & \\
\hline
\end{tabular}

Cumulative variance $\%$.

subsumed by an elite into broader subsystems, supercities. (For ties, see Table 4.)

5. To what degree do subsystems account for the total behavior of the system? Which subsystems play the dominant roles over time? (For principal components'variance, see Table 4.)

6. How do the subsystems behave over time? This can be seen in graphic representations of the relative dominance of the subsystems at various times. (For scores, see Table 5 and subsequent figures.)

PCA and its relative factor analysis come in many variants, each of which takes a slightly different point of view on these six questions. We used PCA because the method makes no assumptions about what are patterns in the data and what is measurement error. All of the data are treated equally, transforming a large number of components into a smaller number of principal components or subsystems. No data are lost; the principal components data (scores) can be transformed back into the original components data. The communality statistic does suggest how much measurement error is present, but this is just a measure of how much of the variation in the components is not cooperative with other components. In this view, a lack of commonality in a component would just mean that it was somehow outside the rest of the system of variables. It resembles genes that do not appear to do anything. They cannot be discounted, because we do not know if there are circumstances under which an apparently nonperforming gene is activated and becomes useful.

There is a variant of PCA specifically designed for network analysis called "network components analysis." Designed by Liao et al. (2003), it is like the graphical network analysis used by Golitko et al. (2012) to analyze Maya obsidian networks and accounts for low-level interaction among the components. The specific case addressed by Liao et al. is patterns generated by underlying regulatory signals from DNA systems. Regular principal components tend to present a picture of interactions at an abstract level and ignore lower level network functions. Deep network investigations may be of future interest when IHOPE-
Maya has codes for several cities within the zones we sampled. The large cities with their urban elites will be the regulatory social functions, and the smaller dependent cities will be the regulated components. However, in this analysis, we are interested in the abstract, inter-subsystem behavior and utilize standard PCA offered in SPSS version 22.

In the PCA we used, the answers to the six questions listed previously are as follows:

1. Correlation: The 10 components (see Table 3 ) were converted into a matrix of correlations (see Table 3, below the diagonal $1.00 \mathrm{~s})$. Correlations show the strength of the relationship between two components at a time. The correlation matrix we used shows 16 pairs that have statistically significant relationships $(<0.05$, above the 1.00 s diagonal) and 29 that do not. A PCA of this matrix will therefore yield a number of statistically independent subsystems. If all of the correlations were significant, there would only be one system. It would be a system in equilibrium as discussed previously. As might be expected, the mix of significances shows that the complex Maya cultural system was not in equilibrium across its 3000-year history.

2. Communality: Table 4 displays the PCA of the 10 components in the central lowlands system. Among the many insights that a PCA provides is a measure of the percent of each component explained by all other components in the system. As can be seen looking down the right-hand "Communalities" column, explanation ranges from a high $100 \%$ (1.00) for the coastal Juan Piojo forest cover measurements to a low of $88 \%$ for Rio Azul ceramic interactions. In other words, the system as measured by these variables is very interactive. If there was little communality, all of the components would be independent or idiosyncratic and the project would be abandoned.

3. Principal Components: The principal components, the five columns of figures we have called "patterns" 1 through 5 , describe how the components cluster into principal components or subsystems. Cells with numbers on the 
Table 5. Principal components analysis scores.

\begin{tabular}{|c|c|c|c|c|c|}
\hline Period & Pat_1 & Pat_2 & Pat_3 & Pat_4 & Pat_5 \\
\hline Hist & -1.28 & 1.74 & -0.69 & -0.80 & 0.35 \\
\hline Lpo & -0.70 & 1.97 & 0.17 & 0.46 & 0.13 \\
\hline Epo & -0.68 & 0.77 & 1.48 & 0.97 & 1.37 \\
\hline $\mathrm{T} 2$ & 0.08 & 0.47 & -0.39 & 1.23 & -2.06 \\
\hline $\mathrm{T} 1$ & 1.06 & 0.19 & -0.72 & 1.12 & 0.70 \\
\hline L2 & 1.07 & 0.07 & -0.43 & 0.89 & -1.44 \\
\hline L1 & 0.69 & -0.73 & -0.15 & 1.06 & 0.89 \\
\hline E3 & 0.93 & 0.12 & 0.73 & -1.39 & 0.76 \\
\hline E2 & 0.97 & -0.19 & 1.55 & -0.81 & -0.15 \\
\hline E1 & 0.60 & 0.19 & 1.10 & -1.46 & -1.44 \\
\hline $\mathrm{Plb}$ & 0.82 & -0.94 & -0.11 & 0.45 & 1.14 \\
\hline Pla & 0.38 & -0.18 & -2.23 & -1.58 & 0.45 \\
\hline $\mathrm{Pm}$ & -0.83 & -0.52 & -1.01 & -0.15 & -0.02 \\
\hline $\mathrm{Pe}$ & -1.27 & -1.36 & 0.31 & 0.11 & -0.35 \\
\hline $\mathrm{Ar}$ & -1.84 & -1.60 & 0.40 & -0.09 & -0.30 \\
\hline
\end{tabular}

principal components of greater than $\sim \pm 0.30$ are considered strong enough to represent a pattern. Taken in combination, the stronger numbers designate the members of a subsystem. For example, in pattern 1, all of the ceramic interactions play important roles except Champoton (0.10). The Silvituc (0.20) and Juan Piojo (-0.02) forests play unimportant roles, but the Peten Itza forest plays a huge role (-0.93). Notice that the relationship between all of the ceramic interactions and the Peten Itza forest is negative relative to all of the interior, urban, ceramic interactions. This negative relationship indicates that the more interaction there is between urban elites, the less forest there is around Lake Peten Itza and, by inference, the interior lowlands. This relationship supports an interpretation that the interior cities are using up their forest resources to maintain themselves and provide for infrastructure. As an independent test of this finding, an article by Lentz et al. (2014) supports this conclusion (see see discussion of patterns 1 and 2 in the Discussion of principal components scores trajectories section).

4. Ties: Ties are instances in which a component participates in more than one pattern. An example is ceramic interactions from Lamanai. Lamanai elites were interacting across four patterns (1-4) of the five $(0.63,0.37,0.47,0.43$, but not 0.02$)$. This is probably because Laminai has such a long history of interaction (Hanna et al. 2016) that if anything was going on anywhere at anytime, Lamanai elites attempted to participate. Some factor analysis methods focus on removing ties by rotating principal component axes away from them. However, if the assumptions of PCA are followed, basically that everything (all variance) is important, then the ties must mean something. As can be seen in the Lamanai case, this analysis suggests that ties are indicating actors who are intruding across subsystems. They may represent the elite actors who are reaching across subsystems to establish supercity institutions. As such, ties would represent positive feedback among other feedback phenomena relative to the larger cities (as discussed previously). It is clear, for example, in pattern 2 that the feedback between Calakmul (-0.29) and Lamanai (0.37) is negative. This might be because of the apparent Calakmul emphasis on overland transportation along the north-south Cancuen-to-Calakmul route.

By way of contrast to Lamanai, in the context of these measurements, Caracol appears to be relatively selfcontained. It only participates in pattern 1 strongly $(0.83)$. This implies that it does participate in the general uptick in ceramic interaction among interior cities during the Classic period. It might also imply that Caracol with its dependable climate was a supplier of goods to other lowland communities rather than a recipient of their goods. This is probably so in the cases of nonperishable goods such as granite from nearby quarries (A. Chase, personal communication, 2016). Other goods, such as perishable agricultural produce, may also have been exported, given the huge amount of managed land in the city and its environs (Chase and Chase 2016).

5. Variance: The amount of total variance in the system is provided at the bottom of Table 4 . The principal component analytic strategy is to extract the variance from the system in the greatest amount first. Thus, pattern 1 represents the primary players in the interaction measurements. As is shown, this accounts for nearly half $(45 \%)$ of all of the system interactions across the history of the central Maya lowlands and $45 \%$ of the total variance. Thus, most of the activity in the history of the Maya system was propagated by the hyperactive interior cities. This, however, does not mean they were resilient as we shall see.

Notice that the coastal cities pattern 2 correlates positively with the coastal forest Juan Piojo (0.65). This indicates that, as interaction increased in the coastal cities, their forest cover increased. They were cultivating their forests rather than using them up. In an ironic outcome, it implies that, as measured by forest impacts, the lower energy coastal cities represented in pattern $2(23 \%)$ left less of a mark on Maya history than the interior cities. The practical outcome, however, is that this version of the society that did not use up its resources was the winner in the long-term goal of sustainability. The interior cities with all of their art and 
learning did not survive. When first sighted by European observers in the 1500s CE, they had been abandoned for hundreds of years. Of course, the 9th-century droughts had an impact, but Heckbert et al.'s (2016) simulation indicates that exhaustion of the land probably also played a major role.

6. Scores: The final insight that PCA offers is how the system components, collapsed into the principal components, behave through time. In our case, we are concerned with how they changed over time. As can be seen in Table 5 and Figure 7 , pattern 1 started out with no interaction based on ceramics in the Archaic (Ar), rose to a great deal of ceramic interaction in the Classic period (E1-L2), and fell again to nothing in the Postclassic (T1-Lpo). By way of contrast, pattern 2, the coastal cities, increased interaction more or less continuously through the whole of the last 3000 years.

Fig. 7. Patterns 1 and 2 plotted against time. Interior (diamonds) and coastal (squares) cities demonstrate different patterns of networking. Interior cities strongly networked during the Late Preclassic (Pla-Plb) and Classic (E1-L2) periods. Coastal cities linked intensively during the Postclassic (T2-Lpo) after a long slow period of development (plotted from patterns 1 and 2 scores, see Table 5).

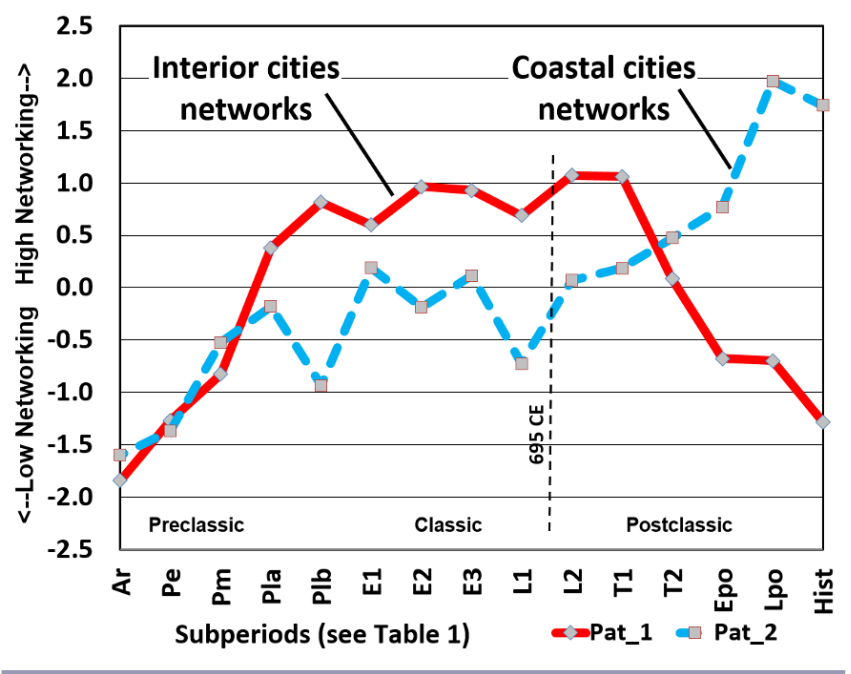

The principal components method that preserves the ties is probably the best way of looking at a complex system and obtaining an idea of how the components of the system interact and how those interactions change over time. Alternative methods such as network analysis are better at presenting detailed spatial variations in data, also without loss of data. PCA allows for more emphasis on the temporal dimension in cultural space-time, although aspects of spatial variation are clearly evident in the principal components as well. It inherently views these processes as a multivariable, complex adaptive system with feedbacks that are connected and influential from time period to time period.

The following discussion of the component score patterns largely uses the findings provided by the answers to question 6 , scores, to investigate the through-time behavior of the various subsystems of the total central Maya lowland ecoinformation system. The answers to question 1-5 are for the most part presented and discussed in Tables 2-5. The scores graphics provide an in-depth view of the workings of the system in terms of its subsystems over the time periods of the study and the city and ecosystem components of the patterns.

\section{DISCUSSION OF PRINCIPAL COMPONENTS SCORES TRAJECTORIES}

At an abstract level, the analysis of these data is an understanding of how their (zone, polity, city) interactions stand as decisions of human agents and as proxies for ecosystem energy flows they created through the history of the central lowlands. The following presents conclusions on the first three of the patterns. The fourth and fifth components are of local concern. At a basic level, the three main patterns involved the trajectories of the interior cities, the coastal cities, and the shifting of information traffic in the central lowlands between the east and west coasts of the Yucatan Peninsula.

- Pattern 1, Interior Cities ( $45 \%$ of variance, see Fig. 7): This pattern represents the largest share of the variance. Its towering cities and water management facilities involved what Tainter et al. (2003) has described as a steepening of the energy gradient during the Classic. These constructions involved increasing use of human and ecosystem energy to design and construct water cities providing for city-scale populations at the edges of the Mesoplano. This brings the interior centers of power closer to the two main arteries of transpeninsular commerce (Freidel et al. 2007, Volta and Gunn 2012, 2016, Gunn et al. 2014). The Preclassic cities of El Mirador, Holmul, Cival, and Ciebal existed near permanent water and in highly bioactive landscapes of a lowland, tropical climate, in the so-called Lake District across the swamps of northern Guatemala. Later Classic period engineering relocated the main centers of power in high and dry southern Campeche (Calakmul), northeastern Guatemala (Tikal), and western Belize (Caracol). They were away from intensely tropical landscapes, but placed there at great energy costs. These costs were both short term in construction and long term in maintenance. It also created in van der Leeuw's (2007) terms "steep information gradients" around these cities capable of performing the rigid requirements of cities as nodes in information and trade exchange networks (see Cowgill 2004). This includes supplying food to a nonproducing population. It is done at high ecosystem services costs that result in reduction of forest cover and soil depletion. So there are a number of covariables involved: information, annual water storage in the wet season and utilization and depletion in the dry season, and agricultural production, also involving water. In short, the pattern is in part one of energy gradients. As is generally recognized, the trajectories of the water cities rose steadily from the Late Preclassic through the Classic and then plunged back to prewater city levels.

- Pattern 2, Coastal Cities (23\% of variance, see Fig. 7): The coastal cities (Coastal) emerged as the dominant players in the Terminal (T1-T2) and Postclassic (Epo-Lpo). Their energy gradients are not steep because their energy demands are much more efficient. They developed marine 
transportation technology during the Preclassic and Classic. Capitalizing on this, they became the core entrepôts during the Terminal and Postclassic. Thanks to inexpensive transportation costs, they were not using their forest cover, but rather building on it through the use of arboriculture during their long ascent to power. This efficient use of coastal area forests has been observed ethnographically on both the east and west coasts (Gunn et al. 2002, Ford and Nigh 2009, 2015). So, the covariables are marine technology, arboriculture, and perhaps international trade as opposed to trade internal to the peninsula. Because the underlying dynastic, ceramic exchanges representing information flow are somewhat limited, we might wonder if there are additional components that would help us understand the character of this economy. Perhaps the nonelite ceramics will prove of use. The coastal cities' trajectories began in the Late Preclassic, similar to interior cities, but subsequently rose at a steady, but lesser, rate than the interior cities. Early on, the interior and coastal cities increased their networking at about the same rate. During the Late Preclassic a (Pla) they split from (bifurcated) the interior cities into two separate trajectories. They also appeared to suffer some setbacks in the Late Classic, perhaps reflecting exploitation by the powerful interior cities.

- Pattern 3, Coasts (12\% of variance, Figs. 8 and 9): This group of covariables appears to turn on a shifting pattern of domination of the east and west coasts of the Yucatan Peninsula. Because the shift from east to west coast power, as measured by elite ceramic exchanges, transpires during the Late Classic period, the shift may have hinged on the transition from dominance by Calakmul to dominance by Tikal. Previous to $695 \mathrm{CE}$, Calakmul was in its golden age under the leadership of Yuknoom the Great. A dashed vertical line in Figure 8 marks the $695 \mathrm{CE}$ transition at the battle of Naachtun, similar to the transition from Late Classic 1 (L1) and Late Classic 2 (L2) subperiods set at 700 CE (see Table 1). After 695 CE, Tikal briefly assumed full control of the central lowlands under the leadership of Jasaw Chan K'awiil I. The covariables would certainly be political and military power and control and transpeninsular trade routes. Martin and Grube (2008) mark the 695 CE conflict as the pivotal moment in Maya history. The final decline of Calakmul's influence seems to have devolved subsequently, taking until about $740 \mathrm{CE}$, by which time all control of the area south of the Tikal region (Petexbatun) fell to Tikal. Climate may also have been a covariable because higher and drier Calakmul seems to have been affected by the events of the Maya collapse earlier than Tikal. This might be a useful simplifying assumption in the debate over whether there was a trend in city collapses in the Late Classic and Terminal Classic

Taking these patterns as reflective of agent-driven decisions opens the conclusions to several recommendations for urban design for the future. Among them would be that the locations of cities should be designed to sustain themselves through long-term rather than short-term climate variations. Twenty-first-century western U.S. cities come to mind (Cook et al. 2015). Cities should be designed to match the ecological conditions in which they are located rather than those suggested by examples external to the immediate environment, such as well-watered New York City, for example.

Fig. 8. East and west coast cities follow alternating paths of networking. West coast cities (represented by Champoton) formed strong networks in the Preclassic and Late Classic to early Postclassic. East coast cities (represented by Lamanai) networked in the early Classic and early Postclassic (plotted from pattern 3 , see Table 5).

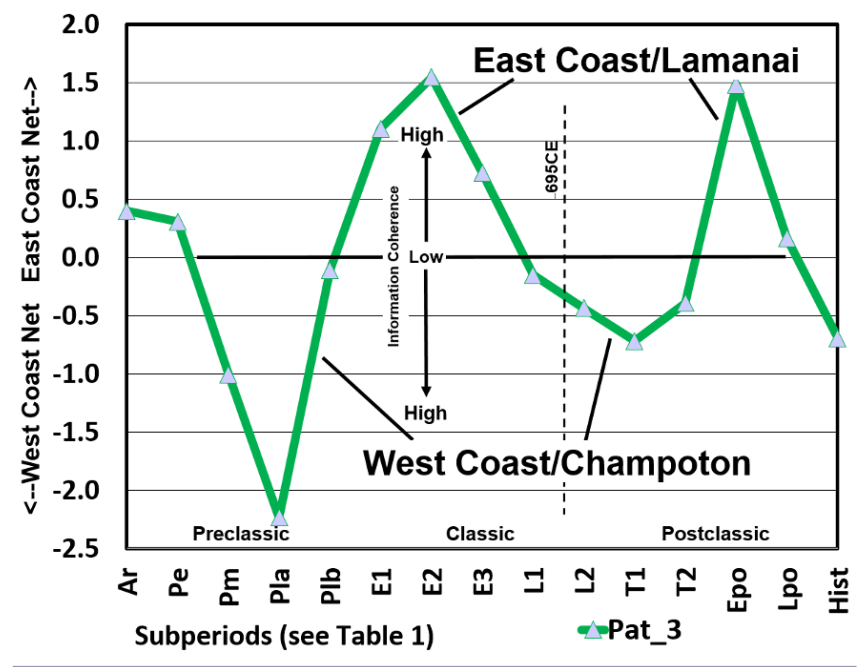

Fig. 9. Maya seagoing shipping in the 11 th century. Note the high prow and stern of the ships to prevent the canoes from being swamped by ocean waves. Oversized people and undersized ships are typical of non-Western depictions of sea travel. (Temple of the Warriors mural, Chichen Itza, Yucatan; watercolor by Ann Axtell Morris; adapted from Martinez de Luna, 2005:81.)

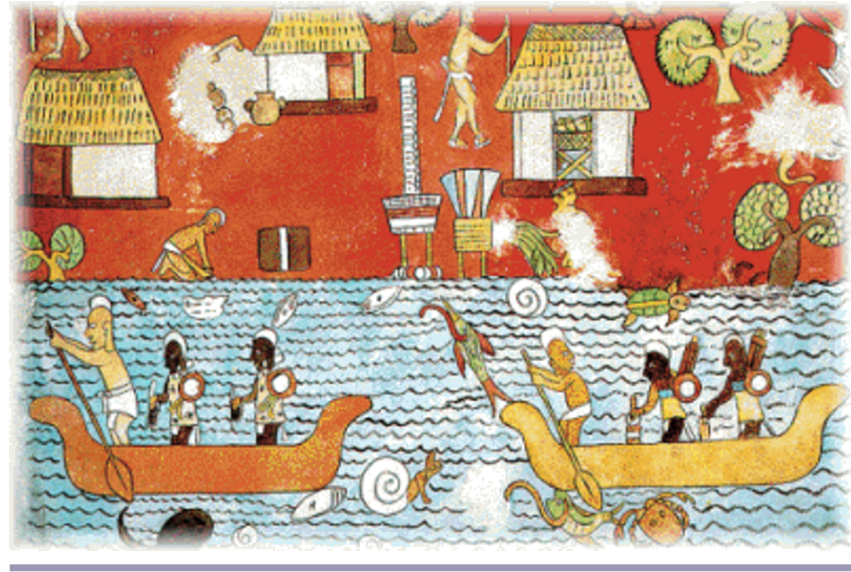

DISCUSSION: BACK TO THE FUTURE

The long history of the Maya cultural evolution provides an opportunity to review the decisions that members of the Maya community made over a 3000-year period. There appear to be two momentous decisions. The first, made by Ch'olan Maya about $1000 \mathrm{BCE}$, was to establish settlements and trade routes 
across the riverine district from the Gulf Coast to east of the Motagua River in Honduras. This appears to have started in the vicinity of the Passion River and spread both east and west (Josserand 2011). The second decision was to abandon the interior of the peninsula as a core economic area and relocate to the coasts and coastal plains around $900 \mathrm{CE}$. Thus, the Maya area became an essentially maritime civilization with interior areas dedicated to providing resources (Sabloff 2007, Gunn et al. 2014).

Exactly who made these decisions cannot be known to us, so they come as decision legacies that lasted as observable outcomes in material culture between about $1000 \mathrm{BCE}$ and $1000 \mathrm{CE}$. That the Maya and their culture survive in strength today, the largest indigenous group in North America, implies that they were basically successful in the long term and endured a multitude of changes. The data indicate that, as a group, the Maya were able and willing to make radical reorganizations of their economy and lifeways when faced with major changes in context. There are possible external factors that might have influenced these decisions. One would have been the arrival of the Olmec civilization about 3000 years ago, apparently offering an opportunity for the Maya to supply Honduran jadeite across the peninsula. The second co-occurs about a thousand years ago with the worst long-term drought in 9000 years (Hodell et al. 1995), resulting in an opportunity for the Maya to take advantage of a new marine culture that had been under development for a millennium.

In the narrower scope of the Classic period (200-900 CE), we can see more clearly who the decision makers were. In some cases, personal names and related deeds in warfare can be assigned. This is especially the case during Calakmul's golden age (from around 500 to 700 CE; Martin and Grube 2008). As discussed previously, an example is Yuknoom the Great (ruling 636-686 CE), a 7thcentury king of Calakmul who presided over the city's apogee (see Figs. 3 and 4 discussion). During this time, Yuknoom and his heir engaged in a struggle for eminence in the central lowland with Jasaw Chan K'awiil I (682-734 CE) of Tikal. Yuknoom's heir, Yuknoom Yich'aak K'ahk', lost a battle with Jasaw at Naachtun in 695 CE setting in motion Calakmul's decline. Tikal gradually replaced Calakmul as the dominant power. The essential lesson is that Yuknoom decided to go to war to maintain Calakmul's preeminence in the face of Tikal's influence, probably a war he inherited from early kings who followed similar lines of decision making. Written records report the considerable energy that earlier Calakmul leaders, such as Scroll Serpent (ruled 579-611 $\mathrm{CE}$ ), put into building a broad, supercity across the central and southern lowlands. His efforts included military expeditions to Palenque in 599 and $611 \mathrm{CE}$, the longest military treks recorded in Maya military history (Martin and Grube 2008). Through these and other means, Yuknoom the Great maintained close relations with a resource colony at Cancuen at the very southernmost point of the lowlands (Demarest et al. 2008, Martin and Grube 2008). Records also point to a long-standing interest by the kings of Calakmul in cities on the Motagua River in Honduras, undoubtedly because of trade network interests established nearly 2000 years before.

During Calakmul's development, Tikal fell under the influence of Teotihuacan in the Mexican highlands in $378 \mathrm{CE}$. Although it is thought that Teotihuacan was interested in controlling the flow of obsidian in the lowlands (Freidel et al. 2007), Tikal remained adversarial to other lowland cities even after Teotihuacan had fallen into disuse after the early 6th century. Although it became a part of the Calakmul-Caracol hegemony following a successful conquest by Caracol in $562 \mathrm{CE}$, Tikal returned to a power position following the $695 \mathrm{CE}$ battle at Naachtun. Jasaw Chan K'awiil presided over the revitalization of Tikal. A century later, starting in about $780 \mathrm{CE}$, the central lowlands experienced wholesale abandonment during a series of extended droughts (Gill 2000, Iannone 2014b). There is some evidence suggesting that the royal house of Calakmul moved to the west coast at Calkini, Yucatan (Folan et al. 2010, 2016). Although there is no direct evidence, it would not be surprising to find that elites from easterly cities such as Tikal and Caracol retreated to nearby coastal cities such as Lamanai. In both cases, moving to the sea would have opened opportunities to participate in the growing mode of life, commerce by the sea.

This brief scenario suggests additional decisions with better information on who made them. First, in the Classic period the commerce in the central lowlands was sufficiently lucrative to sustain dynasties. These dynasties eventually decided to engage in warfare for control of commerce. Second, elements of Tikal's elite were joined or joined in alliances with elements of the highland Mexico commercial establishment, as did Caracol's (Chase and Chase 2011). Third, it became important to aggregate city-sized populations to act as network nodes to control government and commerce at a grand scale. Aggregation at sufficient density was accomplished by building cities engineered to collect rainwater runoff at great cost in labor and ecosystem services. Fourth, under pressure from environmental change and accumulated resource depletion, the interior cities were abandoned in favor of coastal plains cities whose resource bases were marine commerce. Marine commerce did not require much labor mobilization in support of its infrastructure and maintenance because of the much lower cost of transportation.

Looking at the list of decisions made by lowland Maya players provides a basis of comparison with modern world economies. They are also a city-state culture, though at a global scale. Although recognized by social scientists as being a larger and more complex social system, we still refer to them in the vernacular as Washington, Moscow, and Nairobi. Some of the kinds of decisions made by the ancient Maya are still clearly on the minds of modern policy makers. Regional military and trade networks have been a worldwide phenomenon since World War II. They are, in effect, the outgrowths of a decision to join the world in trade to avoid more war. Unfortunately for them, the Maya decision makers seem not to have come to such an agreement. In fact, the external alliance with highland Mexico seems to have aggravated tendencies toward warfare in the lowlands. In this regard, the modern world seems to have progressed somewhat beyond the thought processes of the Maya decision makers of the Late Classic.

Another policy modern bureaucrats can reflect on is the decision on the part of the Tikal elite to emulate Teotihuacan, a city outside their ecological context. Tikal was in the tropics, and Teotihuacan in the high and dry subtropics. The Valley of Mexico is famously more than $2 \mathrm{~km}$ (7000 ft.) in elevation. We can infer that to compete in the Teotihuacan league, the Tikal lowlanders settled 
on aggregation of populations to increase their information exchange capacity. However, life in the tropics typically requires a less aggregated urban foot print (Scarborough and Burnside 2010). Although moving to the more elevated and thus better drained edge of the Mesoplano (Dunning et al. 2013) would have alleviated this problem to some extent, as it partially did at Caracol, it also exposed these aggregated populations to the dangers of long-term drought. The lesson to learn is that policy makers in one climate zone should not assume that what works in one environmental context will provide equal advantage in another. The lesson the decline of many of the interior cities teaches is that in the long-term context of the Maya lowlands, the large, aggregated cities of the Classic were a failed experiment in urban design that fell to the exigencies of local context. The annals of modern foreign aid are filled with failed efforts because firstnation advisers did not take into account second-nation environmental circumstances (Roberts 2009, Day and Hall 2016). The great commercial alliances of the modern world need to be more cognizant of the environmental and ethnic diversity of those seeking aid.

As a general rule, modern decision makers need to learn from the Maya decision to move their centers of operation to a more efficient environment, the coasts in the case of the Maya, but other juxtapositions of population and efficiency can no doubt be designed. Like the Classic period Maya, modern societies need to reorient themselves away from costly modes of transportation and life to inherently efficient ones. Ultimately, all societies that draw more on their environments rather than maintaining them are building toward collapse. This is such a common phenomenon in ancient cultures that anthropologists have a term for it, "resource overshoot."

Finally, also involved with resource overshoot, but in the case of the modern world also involving atmospheric pollution, are the reasons for the 9th-century CE extended droughts. Judging by Ruddiman's (2005) studies of past global climates, the 9th-century droughts were common worldwide because of global cooling caused by reduction of human-produced atmospheric methane. If the Maya culture had had the means, they could have prevented the droughts by injecting methane into the atmosphere. They, or even a worldwide alliance at that time, could not have facilitated this. However, coming to the modern world, our problem is the opposite, too much anthropogenic methane and other trace gases, especially carbon dioxide, threaten modern civilization with runaway global warming. As several efforts show, i.e., the 1992 Kyoto Protocol to the United Nations Framework Convention on Climate Change, 2010 negotiations in Copenhagen, and the 2015 Paris Agreement, modern policy makers are increasingly aware of the need to control worldwide pollution levels. Apart from the obvious need to join in an alliance to control the global environmental circumstance, the lesson on this coincidence of atmospheric issues between the ancient and modern world is that the past may not always have answers to current world problems but may trigger awareness of impending problems.

\section{CONCLUSIONS}

Our experience is that PCA offers a multicomponent view of what has happened over time and through space to complex adaptive systems. It is the appropriate scale of analysis for past civilizations and current ones. It is a method commonly used by modern researchers and deserves the attention of all who aspire to understand local and worldwide, multicomponent systems. Interpreting PCA results benefits from insights gathered from granular, humanistic information on the internal workings of civilizations, opening the possibility of viewing their progress as decision paths by generations of policy makers. Reasoning from decision paths opens the door to comparisons between ancient and modern social processes, thus permitting us to learn from past civilizations that have run their full courses.

Four possible recommendations that past Maya culture has to offer modern societies based on three millennia of experience and our deliberations might be the following: (1) make commerce, not war; (2) do it efficiently relative to ecosystem costs; (3) do not design urban systems based on inappropriate models from other climate zones; and (4) manage the atmosphere if you can. Undoubtedly more will follow.

Responses to this article can be read online at: http://www.ecologyandsociety.org/issues/responses. php/8931

\section{Acknowledgments:}

The authors would like to thank the many members of IHOPEMaya community who contributed both directly as expert observers and indirectly through conversations at the annual gatherings of the working group. Sander van der Leeuw, Foundation Professor, Schools of Sustainability and Human Evolution and Social Change, Arizona State University, guided and sustained the IHOPE-Maya effort through many years of exploration and thinking about appropriate means of understanding not only IHOPE-Maya but the whole IHOPE international enterprise, as did Carole $L$. Crumley, Robert Costanza, and Vernon Scarborough. Rudd Turnbull provided helpful advice on the policy sections of the paper. An early version of this paper was read by Richard E. W. Adams who had lifelong knowledge and experience with culture and travel in the Yucatan Peninsula. Sadly, he did not survive to consider the final version. Thanks Dick. Several institutions contributed conference facilities, food, transportation, and ambience to IHOPEMaya, especially Arizona State University, a persistent supporter of meetings and inspiration. Annual meetings were also held by Schoolfor Advanced Research in Santa Fe, New Mexico; University of Central Florida; The Amerind Foundation; National Center for Ecological Analysis and Synthesis; University of California, Santa Barbara; and University of Cincinnati. We also owe gratitude to Carl Folke, subject editor for Ecology and Society, and two anonymous reviewers.

\section{LITERATURE CITED}

Bentley, R. A. 2003. An introduction to complex systems. Pages 9-23 in R. A. Bentley and H. D. G. Maschner, editors. Complex systems and archaeology. University of Utah Press, Salt Lake City, Utah, USA.

Bocinsky, R. K., J. Rush, K. W. Kintigh, and T. A. Kohler. 2016. Exploration and exploitation in the macrohistory of the preHispanic Pueblo Southwest. Science Advances 2:e1501532. http:// dx.doi.org/10.1126/sciadv.1501532 
Bogucki, P. 2003. The Neolithic settlement of riverine interior Europe as a complex adaptive system. Pages 93-102 in R. A. Bentley and H. D. G. Maschner, editors. Complex systems and archaeology. University of Utah Press, Salt Lake City, Utah, USA.

Brenner, M., M. F. Rosenmeier, D. A. Hodell, F. S. Anselmetti, J. K. Curtis, and D. Ariztegui. 2003. Paleolimnological approaches for inferring past climate change in the Maya region: recent advances and methodological limitations. Pages 45-75 in A. Gómez-Pompa, M. F. Allen, S. L. Fedick, and J. J. JiménezOsornio, editors. The Lowland Maya area three millennia at the human-wildland interface. Food Products, New York, New York, USA.

Capra, F. 2002. The hidden connections: integrating the biological, cognitive, and social dimensions of life into a science of sustainability. Doubleday, New York, New York, USA.

Carrasco Vargas, R., S. Boucher, P. Alvarez González, V. Tiesler Blos, V. G. Vierna, R. G. Moreno, and J. V. Negrete. 1999. A dynastic tomb from Campeche, Mexico: new evidence on Jaguar Paw, a ruler of Calakmul. Latin American Antiquity 10(1):47-58. http://dx.doi.org/10.2307/972210

Chase, A. S. Z. 2016. Beyond elite control: residential reservoirs at Caracol, Belize. Wiley Interdisciplinary Reviews: Water 3:885-897. http://dx.doi.org/10.1002/wat2.1171

Chase, A. F., and D. Z. Chase. 2011. Status and power: Caracol, Teotihuacan, and the Early Classic Maya world. Research Reports in Belizean Archaeology 8:3-18.

Chase, D. Z., and A. F. Chase. 2014. Path dependency in the rise and denouement of a Classic Maya city: the case of Caracol, Belize. Archeological Papers of the American Anthropological Association 24:142-154. http://dx.doi.org/10.1111/apaa.12034

Chase, A. F., and D. Z. Chase. 2016. The ancient Maya city: anthropogenic landscapes, settlement archaeology, and Caracol, Belize. Research Reports in Belizean Archaeology 13:3-14.

Chase, A. F., D. Z. Chase, J. F. Weishampel, J. B. Drake, R. L. Shrestha, K. C. Slatton, J. J. Awe, and W. E. Carter. 2011. Airborne LiDAR, archaeology, and the ancient Maya landscape at Caracol, Belize. Journal of Archaeological Science 38:387-398. http://dx. doi.org/10.1016/j.jas.2010.09.018

Chase, A. F., L. J. Lucero, V. L. Scarborough, D. Z. Chase, R. Cobos, N. P. Dunning, S. L. Fedick, V. Fialko, J. D. Gunn, M. Hegmon, G. Iannone, D. L. Lentz, R. Liendo, K. Prufer, J. A. Sabloff, J. A. Tainter, F. Valdez, Jr., and S. E. van der Leeuw. 2014. Tropical landscapes and the ancient Maya: diversity in time and space. Archeological Papers of the American Anthropological Association 24:11-29. http://dx.doi.org/10.1111/apaa.12026

Chase, A. F., and V. Scarborough. 2014a. Diversity, resiliency, and IHOPE-Maya: using the past to inform the present. Archeological Papers of the American Anthropological Association 24:1-10. http://dx.doi.org/10.1111/apaa.12025

Chase, A. F., and V. L. Scarborough, editors. 2014b. The resilience and vulnerability of ancient landscapes: transforming Maya archaeology through IHOPE. Archeological Papers of the American Anthropological Association Special Issue 24.
Chase, A. S. Z., and J. F. Weishampel. 2016. Using Lidar and GIS to investigate water and soil management in the agricultural terracing at Caracol, Belize. Advances in Archaeological Practice 4(3):357-370. http://dx.doi.org/10.7183/2326-3768.4.3.357

Childe, V. G. 1936. Man makes himself. Watts, London, UK.

Cline, E. H. 2014. 1177 B.C.: the year civilization collapsed. Princeton University Press, Princeton, New Jersey, USA. http:// dx.doi.org/10.1515/9781400849987

Coe, M. D., and M. van Stone. 2005. Reading the Maya glyphs. Second edition. Thames and Hudson, New York, New York, USA.

Cook, B. I., T. R. Ault, and J. E. Smerdon. 2015. Unprecedented 21st century drought risk in the American Southwest and Central Plains. Science Advances 1(1):e1400082. http://dx.doi.org/10.1126/ sciadv. 1400082

Costanza, R., L. J. Graumlich, and W. Steffen. 2007. Sustainability or collapse? An integrated history and future of people on Earth. Dahlem Workshop Reports. MIT Press, Cambridge, Massachusetts, USA.

Cowgill, G. L. 2004. Origins and development of urbanism: archaeological perspectives. Annual Review of Anthropology 33:525-549. http://dx.doi.org/10.1146/annurev.anthro.32.061002.093248

Day, J. W., and C. Hall. 2016. America's most sustainable cities and regions: surviving the 21 st century megatrends. Springer, New York, New York, USA. http://dx.doi.org/10.1007/978-1-4939-3243-6

Day, J. W., Jr., J. D. Gunn, W. J. Folan, A. Yáñez-Arancibia, and B. P. Horton. 2007. Emergence of complex societies after sea level stabilized. Eos, Transactions, American Geophysical Union 88 (15):169-170. http://dx.doi.org/10.1029/2007eo150001

Demarest, A., E. Sears, M. Wolf, M. Forne, and R. Bishop. 2008. High elites, economy, production, and exchange along the Late Classic Maya western trade route. Page 162 in Abstracts of the 73rd Annual Meeting (Vancouver, British Columbia, Canada, 26-30 March 2008). Society for American Archaeology, Washington, D.C., USA.

Demarest, A., P. M. Rice, and D. S. Rice. 2004. The Terminal Classic in the Maya Lowlands: collapse, transition and transformation. University of Colorado Press, Boulder, Colorado, USA.

Diamond, J. 1997. Guns, germs, and steel: the fates of human societies. W. W. Norton and Company, New York, New York, USA.

Diamond, J. 2004. Collapse: how societies choose to fail or succeed. Viking Adult, New York, New York, USA.

Domínguez Carrasco, M. d. R. 2008. Análisis químico y sociopolitico de producción cerámica prehispanica en la región de Calakmul, Campeche. Universidad Autónoma de Campeche, Campeche, Mexico.

Douglas, P. M. J., M. Pagani, M. A. Canuto, M. Brenner, D. A. Hodell, T. I. Eglinton, and J. H. Curtis. 2015. Drought, agricultural adaptation, and sociopolitical collapse in the Maya Lowlands. Proceedings of the National Academy of Sciences of the United States of America 112(18):5607-5612. http://dx.doi. org/10.1073/pnas.1419133112 
Dunning, N. P., T. Beach, L. Grasiozo Sierra, J. G. Jones, D. L. Lentz, S. Luzzadder-Beach, V. L. Scarborough, and M. P. Smyth. 2013. A tale of two collapses: environmental variability and cultural disruption in the Maya Lowlands. Diálogo Andino 41:171-183. http://dx.doi.org/10.4067/s0719-26812013000100011

Durkheim, E. 1893/1960. The division of labor in society. Free, New York, New York, USA.

Durkheim, E. 1897/1951. Suicide: a study in sociology. Free, New York, New York, USA.

Folan, W. J., D. D. Bolles, and J. D. Ek. 2016. On the trail of Quetzalcoat1/Kukulcan: mythic trade routes, interaction networks, and interpolity connections in the Maya Lowlands. Ancient Mesoamerica 27(2):293-318. http://dx.doi.org/10.1017/ $\underline{\mathrm{S} 0956536115000346}$

Folan, W. J., G. Gates, B. Volta, M. d. R. Domínguez Carrasco, R. González Heredia, J. D. Gunn, and A. Morales-López. 2011. Las ruinas de Calakmul, Campeche, México: sus ciudades tributarias y su altiplanicie kárstica del Petén campechano y el norte de Guatemala. Encuentro Internacional de Los Investigadores de la Cultura Maya. Universidad Autónoma de Campeche, Campeche, Mexico.

Folan, W. J., A. Morales-López, R. González Heredia, M. d. R. Domínguez Carrasco, A. Anaya Hernández, J. D. Gunn, and J. K. Josserand. 2010. El Estado Regional de Calakmul, Campeche, México: Descubrimientos Recientes. Pages 59-90 in A. Benavides Castillo and E. Vargas Pacheco, editors. La Peninsula de Yucatán: Investigaciones recientes y cronologías alternativas. Universidad Autónoma de Campeche, Campeche, Mexico.

Folan, W. J., A. Morales-López, R. González Heredia, J. A. Hernández Trujeque, L. Florey Folan, D. Bolles, J. D. Gunn, and M.d. R. Domínguez Carrasco. 2007. The port city of Champoton (Chakan Putun), Campeche, México: a major Middle Preclassicto-Late Postclassic central place on the west coast of the Yucatan Peninsula. Pages 83-106 in E. Vargas and A. Benavides, editors. El Patrimonio Arqueológico Maya en Campeche: Novedades, Afectaciones y Soluciones. Centro de Estudios Mayas, Cuaderno 35. Universidad Nacional Autónoma de México, Mexico City, Mexico.

Ford, A., and R. Nigh. 2009. Origins of the Maya Forest Garden: Maya resource management. Journal of Ethnobiology 29 (2):213-236. http://dx.doi.org/10.2993/0278-0771-29.2.213

Ford, A., and R. Nigh. 2015. The Maya forest garden: eight millennia of sustainable cultivation of the tropical woodlands. Left Coast/Routledge, New York, New York, USA.

Freidel, D. A., H. L. Escobedo, and S. P. Guenter. 2007. A crossroads of conquerors. Pages 187-208 in J. A. Sabloff and W. L. Fash, editors. Gordon R. Willey and American archaeology: contemporary perspectives. University of Oklahoma Press, Norman, Oklahoma, USA.

Fukuyama, F. 2011. The origins of political order: from prehuman times to the French Revolution. Profile Books, London, UK.

Fukuyama, F. 2015. Political order and political decay: from the Industrial Revolution to the globalization of democracy. Farrar, Straus and Giroux, New York, New York, USA.
Gill, R. B. 2000. The great Maya droughts: water, life, and death. University of New Mexico Press, Albuquerque, New Mexico, USA.

Golitko, M., J. Meierhoff, G. M. Feinman, and P. R. Williams. 2012. Complexities of collapse: the evidence of Maya obsidian as revealed by social network graphical analysis. Antiquity 86:507-523. http://dx.doi.org/10.1017/S0003598X00062906

Gunn, J. D., and W. J. Folan. 2000. Three Rivers: subregional variations in earth system impacts in the southwestern Maya Lowlands (Candelaria, Usumacinta, and Champotón watersheds). Pages 223-270 in R. J. McIntosh, J. A. Tainter, and S. K. McIntosh, editors. The way the wind blows: climate, history, and human action. Columbia University Press, New York, New York, USA.

Gunn, J. D., W. J. Folan, C. Isendahl, M. d. R. Domínguez Carrasco, B. B. Faust, and B. Volta. 2014. Calakmul: agent risk and sustainability in the western Maya Lowlands. Archeological Papers of the American Anthropological Association 24:101-123. http://dx.doi.org/10.1111/apaa.12032

Gunn, J. D., W. J. Folan, and H. R. Robichaux. 1995. A landscape analysis of the Candelaria watershed in Mexico: insights into paleoclimates affecting upland horticulture in the southern Yucatan Peninsula semi-karst. Geoarchaeology 10:3-42. http://dx. doi.org/10.1002/gea.3340100103

Gunn, J. D., J. E. Foss, W. J. Folan, M. d. R. Domínguez Carrasco, and B. B. Faust. 2002. Bajo sediments and the hydraulic system of Calakmul, Campeche, Mexico. Ancient Mesoamerica 13 (2):297-315. https://doi.org/10.1017/S0956536102132184

Hanna, J. A., E. Graham, D. M. Pendergast, J. A. Hoggarth, D. L. Lentz, and D. J. Kennett. 2016. A new radiocarbon sequence from Lamanai, Belize: two Bayesian models from one of Mesoamerica's most enduring sites. Radiocarbon 58:771-794. http://dx.doi.org/10.1017/rdc.2016.44

Hansen, M. H. 2000. A comparative study of thirty city-state cultures. C. A. Reitzels Forlag, Copenhagen, Denmark.

Heckbert, S., C. Isendahl, J. D. Gunn, S. Brewer, V. L. Scarborough, A. F. Chase, D. Z. Chase, R. Costanza, N. P. Dunning, T. Beach, S. Luzzadder-Beach, D. Lentz, and P. Sinclair. 2016. Growing the ancient Maya social-ecological system from the bottom up. In C. Isendahl and D. Stump, editors. The Oxford handbook of historical ecology and applied archaeology. Oxford University Press, Oxford, UK. http://dx.doi.org/10.1093/ oxfordhb/9780199672691.013.30

Hegmon, M., M. A. Peeples, A. P. Kinzig, S. Kulow, C. M. Meegan, and M. C. Nelson. 2008. Social transformation and its human costs in the Prehispanic U.S. Southwest. American Anthropologist 110(3):313-324. http://dx.doi.org/10.1111/ j.1548-1433.2008.00041.X

Hibbard, K. A., R. Costanza, C. Crumley, S. van der Leeuw, S. Aulenbach, J. Dearing, J. Morais, W. Steffen, and Y. Yasuda. 2008. Developing an integrated history and future of people on Earth (IHOPE): research prospectus. International GeosphereBiosphere Programme Secretariat, Stockholm, Sweden.

Hightower, J. N., A. C. Butterfield, and J. F. Weishampel. 2014. Quantifying ancient Maya land use legacy effects on 
contemporary rainforest canopy structure. Remote Sensing 6:10716-10732. http://dx.doi.org/10.3390/rs61110716

Hodell, D. A., J. H. Curtis, and M. Brenner. 1995. Possible role of climate in the collapse of Classic Maya civilization. Nature 375:391-394. http://dx.doi.org/10.1038/375391a0

Holland, J. H. 1998. Emergence: from chaos to order. Perseus Books, Cambridge, Massachusetts, USA.

Iannone, G. 2014a. The dynamics of ancient Maya developmental history. Pages 21-50 in G. Iannone, editor. The great Maya droughts in cultural context: case studies in resilience and vulnerability. University Press of Colorado, Boulder, Colorado, USA.

Iannone, G., editor. 2014b. The great Maya droughts in cultural context: case studies in resilience and vulnerability. University Press of Colorado, Boulder, Colorado, USA.

Josserand, J. K. 2011. Languages of the Preclassic period along the Pacific coastal plains of southeastern Mesoamerica. Pages 141-174 in M. Love and J. Kaplan, editors. The southern Maya in the Late Preclassic: the rise and fall of an early Mesoamerican civilization. University Press of Colorado, Boulder, Colorado, USA.

Kauffman, S. A. 1995. At home in the universe: the search for the laws of self-organization and complexity. Oxford University Press, New York, New York, USA.

Kerr, J. 1989-1996. The Maya vase book: a corpus of rollout photographs of Maya vases, 5 volumes. Kerr Associates, New York, New York, USA.

Kroeber, A. L. 1917. The superorganic. American Anthropologist 19:163-213. http://dx.doi.org/10.1525/aa.1917.19.2.02a00010

Lentz, D. L., N. P. Dunning, V. L. Scarborough, K. S. Magee, K. M. Thompson, E. Weaver, C. Carr, R. E. Terry, G. Islebe, K. B. Tankersley, L. Grazioso Sierra, J. G. Jones, P. Buttles, F. Valdez, and C. E. Ramos Hernandez. 2014. Forests, fields, and the edge of sustainability at the ancient Maya city of Tikal. Proceedings of the National Academy of Sciences of the United States of America 111(52):18513-18518. http://dx.doi.org/10.1073/pnas.1408631111

Liao, J. C., R. Boscolo, Y.-L. Yang, L. M. Tran, C. Sabatti, and V. P. Roychowdhury. 2003. Network component analysis: reconstruction of regulatory signals in biological systems. Proceedings of the National Academy of Sciences of the United States of America 100(26):15522-15527. http://dx.doi.org/10.1073/ pnas. 2136632100

Martin, S., and N. Grube. 2008. Chronicle of the Maya kings and queens: deciphering the dynasties of the ancient Maya. Second edition. Thames and Hudson, London, UK.

Martinez de Luna, L. A. 2005. Murals and the development of merchant activity at Chichen Itza. Master of Arts Thesis. All theses and Dissertatons Paper 674. Brigham Young University, Provo, Utah, USA.

Masson, M. A., and D. A. Freidel. 2012. An argument for Classic era Maya market exchange. Journal of Anthropological Archaeology 31455-31484. http://dx.doi.org/10.1016/j.jaa.2012.03.007
McAnany, P. A., J. A. Sabloff, M. Lamoureux St.-Hilaire, and G. Iannone. 2015. Leaving Classic Maya cities: agent-based modeling and the dynamics of diaspora. Pages 231-258 in G. Emberling, editor. Social theory in archaeology and ancient history: the present and future of counternarratives. Cambridge University Press, Cambridge, UK. http://dx.doi.org/10.1017/ $\underline{\text { cbo9781107282056.013 }}$

Miller, B. W., and J. T. Morisette. 2014. Integrating research tools to support the management of social-ecological systems under climate change. Ecology and Society 19(3):41. http://dx.doi. org/10.5751/ES-06813-190341

Mitchell, M. 2011. Complexity: a guided tour. Oxford University Press, Oxford, UK.

Prufer, K., V. Scarborough, A. Chase, D. Z. Chase, R. Cobos, N. Dunning, J. D. Gunn, S. L. Fedick, V. Fialko, G. Iannone, D. Lentz, R. Liendo, L. Lucero, J. A. Sabloff, J. Tainter, F. Valdez, and S. van der Leeuw. 2011. IHOPE Maya: resilience and rigidity in the development and disintegration of complex societies in the tropical lowlands of Mesoamerica. Resilience 2011. Resilience, innovation, and sustainability: navigating the complexities of global change. Second International Science and Policy Conference (Tempe, Arizona, 11-16 March 2011). Arizona State University, Tempe, Arizona, USA.

Pyburn, K. A. 2008. Pomp and circumstance before Belize: ancient Maya commerce and the New River Conurbation. Pages 247-272 in J. Marcus and J. A. Sabloff, editors. The ancient city: new perspectives on urbanism in the Old and New World. School for Advanced Research Press, Santa Fe, New Mexico, USA.

Redfield, R., and A. Villa Rojas. 1934. Chan Kom: a Maya village. Carnegie Institution, Washington, D.C., USA.

Reents-Budet, D. 1994. Painting the Maya universe: royal ceramics of the Classic period. Duke University Press, Durham, North Carolina, USA.

Reents-Budet, D., S. Boucher Le Landais, Y. Palomo Carrillo, R. L. Bishop, and M. J. Blackman. 2011. Cerámica del Estilo Códice: nuevos datos de producción y patrones de distribución. Pages 841-856 in B. Arroyo, L. Paiz Aragón, A. Linares Palma, and A. L. Arroyave, editors. XXIV Simposio de Investigaciones Arqueológicas en Guatemala. Ministerio de Cultura y Deportes, Instituto de Antropología e Historia, y Asociación Tikal, Guatemala City, Guatemala.

Roberts, P. 2009. The end of food. Houghton Mifflin Harcourt, New York, New York, USA.

Ruddiman, W. F. 2005. Plows, plagues, and petroleum: how humans took control of climate. Princeton University Press, Princeton, New Jersey, USA.

Rummel, R. J. 1970. Applied factor analysis. Northwestern University Press, Evanston, Illinois, USA.

Sabloff, J. A. 2007. It depends on how you look at things: new perspectives on the Postclassic period in the northern Maya Lowlands. Proceedings of the American Philosophical Society 151 (1):11-26.

Scarborough, V. L., and W. R. Burnside. 2010. Complexity and sustainability: perspectives from the ancient Maya and the 
modern Balinese. American Antiquity 75(2):327-363. http://dx. doi.org/10.7183/0002-7316.75.2.327

Scarborough, V. L., N. P. Dunning, and F. Valdea. 2003. Heterarchy, political economy, and the ancient Maya: the Three Rivers region of the east-central Yucatan Peninsula. University of Arizona Press, Tucson, Arizona, USA.

Scarborough, V. L., and F. Valdez. 2009. An alternative order: the dualistic economies of the ancient Maya. Latin American Antiquity 20(1):207-227.

Scarborough, V. L., and F. Valdez. 2014. The alternative economy: resilience in the face of complexity from the eastern lowlands. Archeological Papers of the American Anthropological Association 24:124-141. http://dx.doi.org/10.1111/apaa.12033

Schele, L., and D. Freidel. 1990. A Forest of kings: the untold story of the ancient Maya. William Morrow, New York, New York, USA.

Sharer, R. J., and L. P. Traxler. 2006. The ancient Maya. Sixth edition. Stanford University Press, Stanford, California, USA.

Smith, A. 1759. The theory of moral sentiments. A. Millar, A. Kincaid, and J. Bell, London, UK.

Smith, A. 1776. An inquiry into the nature and causes of the wealth of nations. W. Strahan and T. Cadell, London, UK.

Tainter, J. A., T. F. H. Allen, A. Little, and T. W. Hoekstra. 2003. Resource transitions and energy gain: contexts of organization. Conservation Ecology 7(3):4. http://dx.doi.org/10.5751/es-00574-070304

Tainter, J. A., and C. L. Crumley. 2007. Climate, complexity, and problem solving in the Roman Empire. Pages 61-75 in $\mathrm{R}$. Costanza, L. J. Graumlich, and W. Steffen, editors. Sustainability or collapse? An integrated history and future of people on Earth. Dahlem Workshop Reports. MIT Press, Cambridge, Massachusetts, USA.

Torrescano-Valle, N., J. D. Gunn, and W. J. Folan. 2012. Historia Climática y Ambiental del Río Candelaria, Laguna Panlao 4,000 Años Antes de Cristo. Pages 49-63 in R. Cobos, editor. Arqueología de La Costa de Campeche: La Época Prehispánica. Ediciones de la Universidad Autónoma de Yucatán, Mérida, Yucatán, Mexico.

Torrescano-Valle, N., and G. A. Islebe. 2015. Holocene paleoecology, climate history and human influence in the southwestern Yucatan Peninsula. Review of Palaeobotany and Palynology 217:1-8. http://dx.doi.org/10.1016/j.revpalbo.2015.03.003

Turner, B. L., II, and J. A. Sabloff. 2012. Classic Period collapse of the Central Maya Lowlands: insights about humanenvironment relations for sustainability. Proceedings of the National Academy of Sciences of the United States of America 109(35):13908-13914. http://dx.doi.org/10.1073/pnas.1210106109

van der Leeuw, S. E. 2007. Information processing and its role in the rise of the European world system. Pages 213-241 in R. Costanza, L. J. Graumlich, and W. Steffen, editors. Sustainability or collapse? An integrated history and future of people on Earth. Dahlem Workshop Reports. MIT Press, Cambridge, Massachusetts, USA.
Volta, B., and J. D. Gunn. 2012. Análisis de costo mínimo de posibles rutas de intercambio trans-peninsulares en el Petén campechano. Page 47 in 54th International Congress of Americanists: building dialogues in the Americas (Vienna, Austria, 15-20 July). University of Vienna, Vienna, Austria. [online] URL: http://ica2012.univie.ac.at/fileadmin/user_upload/DOEVL_events/ ICA/Resumenes Abstracts 54 ICA Viena 2012.pdf

Volta, B., and J. D. Gunn. 2016. The political geography of longdistance trade in the Maya Lowlands: comparing proxies for power structure and exchange networks. Page 464 in Abstracts of the Society for American Archaeology 81st Annual Meeting. Society for American Archaeology, Washington, D.C., USA. 